\title{
LOS MEDICOS MURCIANOS EN EL SIGLO XV
}

\author{
Dr.
}

JUAN TORRES FONTES 
1. La medicina murciana en el siglo XV.-2. Tribunales médicos y alcaldes mayores.-3. El doctor Diego Rodríguez, alcalde y examinador mayor de los cirujanos de Castilla.-4. Los médicos cristianos.5. Fisicos judios. - 6. Los conversos. -7. Un cirujano granadino.-8. Los barberos.-9: La apuesta de un cirujano.-10. Apéndice documental.

\section{LA MEDICINA MURCIANA EN EL SIGLO XV}

En ocasiones parece procedente justificar la elección del tema. Quizá sea ésta una de ellas. Y comienzo diciendo que no escribo para médicos ni pretendo hacer una historia médica de la Medicina murciana en el siglo XV. Lo hago para satisfacer mi curiosidad y pensando que también puede interesar a otras personas un conocimiento más amplio de este tema. No se trata, pues, de una historia para médicos, sino del resultado de la búsqueda por las fuentes historiográficas y fondos documentales a mi alcance sobre quienes durante tres cuartos de siglo fueron protagonistas, mayores o menores, en el escenario médico de una Murcia que, 
sin prisas, aunque en sus principales dirigentes todo fuera acción, violencia y pasión, mudaba su faz y mejoraba sus atavios.

También el título puede resultar cronológicamente excesivo, ya que en realidad se autolimita a setenta y cinco años, toda vez que para la época de los Reyes Católicos contamos con un documentado estudio del doctor Quesada Sanz y no es cuestión de repetir lo ya dicho.

Se trata de esbozar la proyección médica de moros, judíos, conversos y cristianos en la vida murciana en el transcurso de los reinados de Juan II y de Erique IV. No intento a través de ellos obtener una valoración trascendente, ciertamente discutible, para con el ejemplo murciano generalizar a escala más alta. Pero en este largo período de crisis - crisis de crecimiento, claro está - que son los siglos XIV y XV, las diferencias no son tan grandes como para singularizar $y$ aislar un normal desarrollo ciudadano en cierta manera paralelo a los que tienen lugar en otros muchos núcleos urbanos de los reinos castellanos. Una misma época, una geografía física y humana muy próximas, una sociedad similar y unos acontecimientos políticos que repercuten casi por igual en todas partes. producen los mismos problemas y se resuelven de forma semejante.

La Medicina, como profesión, es de amplio signo y con un significado positivo. Es, al mismo tiempo, el mejor medio de comunicación social, puesto que pone en frecuente contacto, directa o indirectamente, a gentes de distinta procedencia, de diferente escala social y de diversa religión. Existen prejuicios, obstáculos e impedimentos legales que separan y dificultan la vida de relación social entre las tres razas, pero ninguno de ellos es decisivo y menos cuando la necesidad impone sus argumentos. La Medicina tiene así una doble relación pues por una parte continúa su desarrollo científico, mejora sus métodos y avanza en alguno de sus medios de acción merced a la actividad de todos cuantos dedican su vida al ejercicio de esta profesión; por otra, diferenciados por su raza y religión, sus posibilidades son distintas, por lo que estan condicionados parcialmente en cada momento histórico.

El médico en sí no es todavía un ente social diferenciado. Es una profesión, un oficio más en la vida de relación ciudadana, para el que se 
tiene toda clase de atenciones, en donde se conjuntan la necesidad y el agradecimiento. Pero en el transcurso del siglo XV comienza a establecerse en Murcia una escala científica médica, consecuencia de la realización de estudios universitarios. $\mathrm{Y}$ junto a los nuevos títulos y a la normal evolución de la vida, de vez en cuando surge lo nuevo, lo original, lo inédito, que lucha contra la supertición, contra la costumbre y contra la incredulidad. Y se produce el choque, el problema. Uno de ellos, resuelto con la seguridad que proporciona la confianza en sus propios conocimientos, es el de Diego Sánchez, cirujano oriolano.

Pero lo normal, lo que es un problema cotidiano, lo que se repite todos los días, es la falta de médicos y cirujanos competentes y en número suficiente. Y la necesidad obliga a olvidar leyes y buscar los procedimientos más rápidos para su solución : la utilización de los físicos y cirujanos judíos; no es un caso, son muchos casos. Existe también el enfermo con medios económicos poderosos que, imposibilitado a desplazarse al lugar donde reside un médico afamado, no escatima gasto para conseguir su asistencia y convencer al cirujano a que viaje. Este es otro caso, el de un cirujano granadino que acude a Murcia a ejercer momentáneamente su profesión y al que se contrata para que permanezca en ella.

Pero antes de exponer algunas de estas proyecciones debemos conocer, aunque sea en apretada síntesis, la ciudad y la sociedad que en ella convive en este tiempo.

La situación geográfica del reino de Murcia en la Edad Media ofrece dos consecuencias inmediatas: una, su condicionamiento militar, el tener que ser primordialmente una marca fronteriza, ya que siendo el único litoral de Castilla en el Mediterráneo y no existiendo fuerzas navales que protegieran sus costas, las incursiones de los corsarios musulmanes y cristianos fueron tan frecuentes como dañinas; al mismo tiempo que siendo limítrofe con los reinos de Granada y Aragón, con extensas y despobladas fronteras, el murciano ha de subordinar todas sus actividades a la seguridad del territorio; pero mayor peligro aún, y la amenaza es persistente, son las incursiones de los almogávares granadinos que penetran profundamente en territorio cristiano y con sus cautivaciones $y$ 
robos obligan al abandono de los campos y la concentración de la escasa población en los recintos urbanos amurallados.

La otra, derivada de éstas, es la escasez de población, pues no existe aliciente ni compensación posible que atraiga e incite al asentamiento de nuevas masas repobladoras. Por otra parte, la gran crisis del siglo XIV afecta profundamente a todo el reino, pues la guerra civil y dinástica; Peste Negra; descalabro militar y derivaciones económicas de las pretensiones portuguesas de Juan I y la minoría de Enrique III, que supone para el territorio murciano dos fuertes quebrantos: guerra civil entre "Manueles y Fajardos", que divide en tres parcialidades a todos los habitantes del adelantamiento, y una mortífera epidemia de peste que liquida a más de la mitad de la población del reino. Esta es la carga que pesa y frena el desarrollo político, social y económico del territorio murciano al finalizar la décimocuarta centuria.

Pero la llegada del nuevo siglo parece presidir un cambio, un giro realmente espectacular. No ha habido persecución religiosa contra los judíos y su aljama, pese a la guerra civil, no sufre daño alguno merced a la eficaz protección del obispo. Tampoco existe malquerencia contra la reducida minoría mudéjar que permanece en el arrabal de la Arrixaca, por el contrario, la ayuda económica concejil manifiesta el deseo de su permanencia. Es entonces, en un escaso período de tiempo, cuando con una vitalidad impresionante. la población murciana supera todo lo pasado y emprende briosa una actividad cada vez más firme.

En este renacer es posible valorar un crecimiento también muy destacado de los mercaderes procedentes de la península italiana, entre los que preponderan los genoveses, que se asientan de forma permanente en la ciudad. Comercio e industria atraen a nuevas gentes, que bajan en su mayor parte de la gobernación aragonesa de Orihuela. Los corregidores imponen el orden y la prosperidad económica se patentiza en construcciones urbanas importantes, entre las que destacan por su carácter oficial: un nuevo puente, una nueva casa municipal y un nuevo alcázar real; se inicia una obra multisecular: nueva catedral; se amplían las tierras de cultivo con desecación de zonas pantanosas en las proximidades 
de la capital. Ciudad, huerta y población crecen. La paz enriqueña ofrece en 1406 brillantes perspectivas.

Tengamos también presente un tercer factor en la contabilidad general y es la frontera como signo positivo, frente al negativo antes enunciado. Fronteras vivas, con actividad incesante tanto en la guerra como en la paz como medio de comunicación y contacto. En la guerra son los alfaqueques encargados de la redención de cautivos los agentes del intercambio, los portadores de información y novedades; en la paz es el comercio quien abre puertas y facilita posibilidades de acercamiento $y$ satisface necesidades de todas clases.

En 1411 tiene lugar un hecho trascendente: la visita y prolongada estancia de San Vicente Ferrer. Lo que supone un clima de exaltación religiosa; unas ordenanzas antijudaicas, precedente de las que al año siguiente promulga la reina doña Catalina con el asesoramiento también del fraile valenciano, y la conversión, sincera o no, de gran número de los judíos de su aljama. Surge entonces el converso, que comienza a ser problema en el orden económico; la protección y amparo de reyes, adelantados, obispos y concejos dispensan a unos y otros, a judíos y conversos, impide que el problema sea también religioso. De este se encargará, o lo creará, la Inquisición cuando haga acto de presencia en Murcia, pero es cuestión que cae fuera de nuestro limitado horizonte.

Otro aspecto a tener en cuenta es que el territorio murciano, por su vecindad a Aragón, no puede eludir y dejar de sufrir los efectos de la contienda política que promueven los infantes de Aragón primero y la oligarquía nobiliaria después. La guerra civil unas veces, la lucha por el predominio del adelantamiento entre los Fajardo durante más de cuarenta años y las arremetidas granadinas, cuando no las oriolanas, son noticias permanentes y protagonizan el desarrollo histórico del reino en estos años.

Pero si la pugna es continua, también es posible advertir una insospechada vitalidad, evidentes mejoras urbanas, "señorialización" ciudadana y una fuerza económica aparentemente inexplicable. La persistencia y continuo aumento de las colonias de mercaderes genoveses y lombardos, así como de los que habitan en el recinto de la judería, es indicativo de esta 
prosperidad, pese a las perturbaciones que se suceden de forma casi ininterrumpida, propias del intenso ritmo de crecimiento que se manifiesta en todos los órdenes de la vida.

Pero conviene matizar y sentar una base de partida. En cuanto se refie. re a la ciudad de Murcia deben tenerse siempre presentes las equívocas cifras que circulan sobre su población, muy inferior a las que repetidas veces se han publicado y cuya justificación descansa en un simple cálculo y no en testimonios documentales; y mucho más si se refieren al despoblado reino de Murcia. Una fase de descenso, que en algunos momentos adquiere alarmantes proporciones, es la que transcurre aproximadamente desde 1276 a 1306; de recuperación, con evidentes regresiones intermedias, son las que tienen lugar en dos etapas, hasta 1372 y hasta 1398 respectivamente.

Superados los dos últimos obstáculos, epidemia de peste que produce la baja de la mitad de la población y por otra parte la guerra civil, el siglo $\mathrm{XV}$ es de signo positivo, aunque muchas causas, ponen freno al avance: repetición de epidemias, plagas de langosta, desastrosas avenidas del río Segura, guerra civil, nueva mentalidad económica que encamina a los más ambiciosos por otros derroteros, y supone también el aumento de las exigencias tributarias, que empuja a muchos, cristianos, moros y judíos a trasladarse a vivir al vecino reino de Aragón, lejos de los apremios fiscales, y de donde no todos vuelven.

Una última nota. Los artículos que siguen, escritos sin continuidad, en distintos tiempos, aunque traten de un mismo tema en una misma época, no pretenden ofrecer una visión de conjunto de la Medicina murciana en el transcurso de setenta años. Lo que explica la aparente reiteración de conceptos o posible repetición de algún dato. Falta mucho para intentarlo, tanto por lo que se refiere a nuestros conocimientos de la propia historia murciana, como al desarrollo y vicisitudes de la Medicina en otras ciudades castellanas. 


\section{TRIBUNALES MEDICOS Y ALCALDES MAYORES}

La falta de médicos y sobre todo de cirujanos es una constante que se mantiene en Murcia sin grandes oscilaciones en los tres últimos siglos medievales (1). Es posible apreciar en las Actas concejiles la preocupación de los regidores por atender este servicio ciudadano y cómo contratan o conceden gratificaciones anuales a físicos y cirujanos para asegurar su permanencia en la ciudad. Por ello, a pesar de las leyes que desde comienzos del siglo XV se intensifican prohibiendo toda asistencia médica de judios a cristianos, regidores y jurados obligados por las circunstancias las olvidan y recurren a contratar y no dudan en autorizar a físicos y cirujanos judíos para que presten sus beneficiosos servicios a la población. Porque, además, se da el caso de que es exclusivamente en los judíos donde unicamente se encuentra una continuidad familiar en esta profesión, por lo que es siempre mayor su número, la seguridad de su permanencia y al mismo tiempo menores sus exigencias económicas.

La utilización por concesión del rey Sabio del Fuero Real como fue. ro supletorio en la ciudad de Murcia permite deducir que desde el siglo XIII se cumplió lo dispuesto en su ley I, título XVI del libro IV: "Ningun home no obre de fisica, si no fuere aprobado por buen fisico por los fisicos de la Villa do hubiere de obrar, e por otorgamiento de los alcaldes, e sobre esto haya carta testimonial del Concejo, y esto mesmo sea de los Maestros de las llagas, e ninguno de ellos no sean osados de tajar, ni defender, ni de sacar huesos, ni de quemar, ni de melicinar en ninguna guisa..."

Obligación de examen ante el Concejo de físicos y cirujanos de que nos quedan testimonios murcianos del siglo XIV y más abundantes en el XV. Un mínimo de seguridad hizo que el Concejo así lo exigiera a todo físico o cirujano que llegaba a la ciudad, o que, siendo vecino de ella, alcanzara la edad y poseyera los conocimientos que se consideraban precisos para ejercer su especialidad. Estos exámenes, especialmente los de

(1) Para la Medicina Murciana en el siglo XIII, vid. Torres Fontes. Un médico alfonsi: Macestro Nicolds.-Murgetana, VI, 1954, 9-16. 
físicos, eran juzgados normalmente por frailes de Santo Domingo o del monasterio de San Francisco, doctos en Filosofía y Teología, y cuyos conocimientos en Medicina no debían ser muy profundos; aunque junto a ellos se repite la presencia de algún físico o cirujano judío, que sin duda responde a su competencia científica para poder formular las preguntas de rigor y juzgar la experiencia y saber del examinado. Al mismo tiempo denota la falta de médicos cristianos, pues cuando los hay no se vacila en utilizar sus servicios. Lo que por consencuencia nos ha permitido en más de una ocasión el conocimiento de alguno de ellos, aunque solo sea en su identificación nominal.

Generalmente este examen se efectuaba en la sala de juntas municipal y con asistencia de regidores y jurados. Predominaba la Filosofía, a veces la Teología y en otras la Astrología en los ejercicios teóricos y una operación o tratamiento al caso en los prácticos de los cirujanos. La aprobación proporcionaba un testimonio por escrito del concejo en que se hacía constar los nombres de quienes le habían juzgado y el acuerdo municipal declarando su aptitud, lo que le facultaba para el ejercicio de su profesión en la ciudad y su jurisdicción.

La realización de estos exámenes se mantuvo como privilegio municipal hasta muy avanzada la segunda mitad del siglo $X V$, pese a que en 1420 se dispuso por Juan II que sólo tuvieran validez los exámenes efectuados por los alcaldes mayores o sus comisionados. Pero es tan solo, ya en la época de los Reyes Católicos, al reorganizarse el protomedicato en 1477, cuando iba a tener plena efectividad esta disposición.

Hombres de todas las razas y religiones ejercen la Medicina y Cirugía. Ante su necesidad, pese a la leyes, a las diferencias sociales y a las discriminaciones que se mantienen en las restantes relaciones ciudadanas, el ejercicio de la Medicina no tuvo limitaciones ni fronteras, ni siquiera en los momentos álgidos de antisemitismo, en que se prohibe terminantemente la relación médico-judío y enfermo-cristiano.

Tampoco existe una clasificación social que diferencie en el campo del trabajo a los físicos y cirujanos, fuera de las propias raciales y religiosas. Lo que se prueba por las soldadas o ayudas económicas que 
anualmente se conceden por acuerdo concejil para garantizar su permanencia, ya que todos, sin distinción social o étnica, reciben igual cantidad y todos procuran su concesión. Tan sólo al crearse en 1432 el médico de pobres, es cuando oficialmente se establece una diferencia social en la asistencia médica entre los ciudadanos. Otra cosa es cuanto se refiere a judíos y mudéjares, a quienes atenderían hombres y mujeres de su misma condición étnico-religiosa.

El mundo médico murciano en el siglo XV es manifiestamente pobre en cuanto al número y calidad de profesionales y en cuanto a las posibilidades de asistencia hospitalaria. Se encuentra muy lejos de ese otro tan amplio y variado de Valencia en la misma época, que tan brillantemente nos describe García Ballester (2). Nos consta que a los leprosos se les prohibía salir de casa bajo severas penas y en otra ocasión, en 1457, los regidores dieron orden al alguacil para que hiciera cumplir su acuerdo respecto a un cristiano y un judio "que son gafos, que fasta tres días salgan de la çibdad e su termino, so pena de muerte". Actitud que se modifica en 1465 con un vecino, pues teniendo conocimiento de que Diego de Ortega había enfermado de "gafedad, la qual enfermedad segund relaçion de fisicos se pega, e por apartar este daño de los vezinos desta çibdad, la qual por grazia de Nuestro Señor está muy linpia de semejantes enfermedades e porque el dicho Pedro de Ortega e ansi mesmo su fijo son muy pobres, que non tiene para lo poder levar a la çibdad de Toledo, onde ay casa para estos omes de semejantes enfermedades, porque esté allí e le curen", acordaron auxiliarle con quinientos maravedís como ayuda para su viaje. El mismo alcance tiene otro caso de remisión de un loco a Valencia. Por lo que conocemos de la relación de enseres y reducida capacidad del hospital de San Antón (3), era tal su pobreza y limitación, que justifican también este criterio negativo que en general nos produce la Medicina murciana en los siglos medievales.

(2) Luis Garcia Ballester, Aproximación a la bissoria social de la Medicina bajomedieval en Valoncia, Salamanca, Cuadernos de Historia de la Medicina Española, VIII, 1969, 45.78.

(3) Torres Fontes, El bospital do San Ansón, en Bol. Inf. del Apuntamiento de Murcia, 1968, págs, 36-38. Del hospital de S. Salvador, una sola meación en 1466, no dice nada. 
La falta de legislación y de normas que regularizaran el ejercicio público de una profesión como la de físicos y cirujanos, daban lugar a que municipalizada la Medicina, todo quedara al libre arbitrio concejil. cuyas exigencias variaban en cada momento. Al ser muchos los llamados a decidir y dejarse sentir las influencias ajenas, la consecuencia era un bajo nivel cientifico y la multiplicación de aventureros que procuraban embaucar con sus supuestos conocimientos e interpretaciones la credulidad de las gentes, ya de por sí extremadamente superticiosas. Lo que motivaría que don Fernando de Antequera reprodujera en 1410 las disposiciones prohibitivas insertas en las Partidas contra adivinos y hechiceros, cabalistas y espiritistas, que seguian engañando y fomentando la candidez de los incautos castellanos y la imposición de graves penas: muerte, destierro y multas, así como su orden de que "vos las justiçias fagades leer este mi ordenamiento en consejo público a canpana repicada una vez en cada mes en día de mercado" (4).

Los nuevos tiempos, el autoritarismo monárquico que comienza a imponerse no por la fuerza sino a través de una red de disposiciones cada vez más extensa y compacta, la misma complejidad de la vida y la consiguiente multiplicación de atenciones y problemas, obligan a los reyes castellanos en la segunda mitad del siglo XV a crear una serie de instituciones destinadas a controlar y organizar de forma adecuada las principales manifestaciones públicas de la vida castellana. De esta forma, las nacientes instituciones encaminadas a la puesta en marcha de nuevos servicios, son al mismo tiempo órganos de centralización y de intervención del poder real.

No todas las nuevas instituciones fueron eficaces o tuvieron inmediatos resultados, pues muchas de ellas no llegarian a demostrar su utilidad

(4) "omes e mugeres que van contra este mandamiento usando destas manctas de adevinança, conviene a saber: de agüeros de aves, e de estornudos, e de palabras que llaman prorerbios, e de suerte e de fechizos, e catan en agua o ea cristal, o en espada o en espejo o en otra cosa luzia, e fazen fechizos de metal n en orra cosa qualquier, o de adevinança de cabeca de ome muerto o de bestia, o de palma de niño o de muger virgen $o$ de encantamientos e de cereşos e de ligamentos de casados, e cortan la rosa del monte porque sana la dolençia que llaman rosa..." 
hasta los Reyes Católicos, pero la idea, la creación o propósito quedaban ya señalados. Sucede así con el primer intento de la Monarquía de querer controlar el ejercicio de la Medicina mediante la exigencia de obligar a un examen ante el físico real (5). Cosa que no iba a tener efectos duraderos. Pero no deja de tener interés por dos razones esenciales. Una, es por lo que significa de desconfianza para los que practicaban como físicos y cirujanos por nombramiento o con autorización concejil, y otra por cuanto representa este primer fundamento del protomedicato. Uno de los casos que conocemos ofrece también la peculiaridad de que es el examen de un físico sevillano, judío, ante Juan Guillén, físico de Juan I, lo que evidencia una vez más como prácticamente no existía discriminación a la hora de la necesidad o de la conveniencia.

La tercera fase de la Medicina bajomedieval tiene lugar con Juan II. Todas las funciones que desempeña el concejo en cuanto a su derecho a nombrar jueces especialistas en la materia para conocer los conocimientos de los aspirantes y el de presenciar los exámenes para su mayor garantía, así como el de otorgar la correspondiente carta de licencia, que al mismo tiempo certificaba la aptitud del examinado, es lo que Juan II intenta restarles con la designación de los alcaldes mayores y la facultad para nombrar lugartenientes o delegados en los reinos castellanos, con el objeto de abarcar la totalidad del territorio y lograr un fin práctico y provechoso para todos.

Los concejos reaccionaron de forma diversa, si bien predominando los que se negaron a aceptar esta modalidad que les privaba de un derecho tradicional al estimar que quebrantaba sus fueros y privilegios. Por

(5) Hernández Morejón, Historia bibliogrdfica do la Medicina española, Madrid, fomo I, 1842, indica, sin concretar fecha, aunque atribuyéndolo a Juan I, la creación de dos alcaldias mayores: "cré examinadores, que llamó alcaldes, para que estos conociesen la aptitud de los que se dedicaban a la medicina o cirugia...- $Y$ para que los médicos y cirujanos sufriesen exámenes por medio de alcaldes examinadores de uno otro ramo" (págs. 243.4).

Por su parte Ruiz Moreno, Aníbal, La Modicina en la logislación medieval espariola, Buenos Aires, 1946, señala un antecedente con Enrique II, puesto que en el Ordenamiento de Chancilleria, en las Cortes de Toro de 1371, el rey. fija el pago de la carta que se expedia al físico o cirujano después de haber sido examinado y que le autorizaba a su vez para examinar, en 600 maravedis (Cortes do los antiguos roinor de León y de Castilla, II, Madrid, 1863. pág.. 227). 
ello acudieron a la socorrida puesta en práctica de la concesión enriqueña que autorizaba a que las disposiciones reales que se consideraran antiforales fueran obedecidas pero no cumplidas. Lo que suponía un aplazamiento, a veces indefinido. $Y$ por ello continuaron designando sus tribunales y expidiendo certificaciones de exámenes y aptitud para el ejercicio de la Medicina y Cirugía y desconociendo la autoridad de los alcaldes mayores y sus lugartenientes.

Aunque no todos, porque en la ciudades y villas donde los corregidores habían logrado imponerse, pudieron obligar a que se cumplieran las disposiciones reales o impedir el ejercicio de la profesión a los que no hubieran tenido la aprobación o confirmación de su aptitud del protomédico o protocirujano real. Lo prueba la persistente queja de los procuradores representantes de las ciudades en las reuniones de Cortes. En las de Zamora de 1432 protestaban de que se les quebrantaban sus privilegios y de que eran "fatigados y cohechados", pidiendo que los alcaldes mayores no usaran de sus oficios; a lo hábilmente contestó Juan II dando su conformidad a la suspensión y prometiendo que no usarían de sus alcaldías sin su especial mandado, para lo que daría sus cartas. Pero en las Cortes de Madrid de 1435, al reproducirse la queja, se dice que no sólo no habían cumplido lo ordenado por el rey, "antes han ganado nuevas cartas de vuestra merçed en contrario dello, llevando encorporadas en ellas la dicha ley".

Resumen de las dos anteriores es la misma exposición en las Cortes de Madrigal de 1438, pero con graves acusaciones contra los alcaldes mayores y sus lugartenientes, porque aprobaban a "personas inabiles e non suficientes ni sabidores de los tales oficios, de lo qual se siguen muchos peligros e dapnos en los cuerpos e personas de los omnes e mugeres, que quando el fisico es tal que non conosçe ni sabe curar de la enfermedad nin el çerugiano de la llaga e así por semejante los otros oficios, ante mueren muchos que guaresca uno" (6).

La propuesta que los procuradores hacen al monarca supone una cesión parcial de sus tradicionales derechos, puesto que aceptaban que el

(6) Contes de Lebn y Castilla, III, 139-40, 226 y 317-8. 
examen lo efectuara el alcalde mayor o su lugarteniente, pero a presencia de la justicia municipal o de dos regidores "porque sepan si el tal esaminado es pertenesçiente para usar de tal ofiçio". Una nueva evasiva del monarca, significaba un paso hacia adelante para su total control. Pero no iba a ser así. Si prestamos atención a las fechas de estas protestas de los representantes municipales en las Cortes, podremos advertir que tienen lugar entre 1432 y 1438, o sea, en los años de mayor poderío de don Alvaro de Luna, el cual en 1439 salía desterrado por segunda vez de la corte. El privado no iba a alcanzar otro período de gobierno enteramente personal, lo que explica que no se repitan las quejas de los procuradores, puesto que no se produce causa que motive nuevas protestas. La pugna Monarquía-Nobleza iba a debilitar el poder real y los municipios volverían a imponer el cumplimiento y observancia de sus fueros y privilegios, incluso frente a la oposición de los corregidores, cuya temporalidad en el cargo, otra vez incierta e insegura, no les permitiría luchar con igual fe y firmeza por el cumplimiento de todas las disposiciones reales dictadas en los años anteriores, y menos aun por las que no eran trascendentales.

El ordenamiento de 1420 de Juan II diferencia dos técnicas distintas: Medicina y Cirugía y por ello crea dos alcaldías mayores colegiadas (7). Al frente de cada una de ellas un doctor en Medicina y un maestro especialista en cada materia. Las delegaciones que independientemente otorgan, el protocirujano mayor doctor Diego Rodriguez y el protomédico doctor Juan de Toledo al bachiller Francisco López eran completas, pues se extendían tanto a examinar a los que quisieran profesionali-

(7) Aunque hemos transcrito el documento de nombramiento como protocirujano mayor a favor del Dr. Diego Rodríguez, ul faltarle su encabezamiento y, sobre todo, en la duda de si ha sido ya publicado, decidimos no incluírlo en el apéndice. Es lugar adecuado también para decir que no me ha sido posible consultar la obra de Isidoro de la Villa, Los médicos, la Medicina en la época de los Reyos Católicos, Valladolid, 1939. Pero no deja de ser curioso el equivoco que existe en cuanto a la fecha de la designación de los alcaldes mayores por Juan II. Porque desde Chinchilla (Anales bistóricos do la Medicina... Historia de la Medicina española, Valencia, 1841, I, 90), hasta Aníbal Ruiz Moreno, (La Medicina en la legislación medieval española. Buenos Aires, 1946, pág. 24), se data en el año 1422, que en la secién Historio Universal de la Medicina, III. Edad Media, Barcelona, Salvat, 1972, pág. 349 se lleva a 1432. 
zarse en el ejercicio de la Cirugía y Medicina, fueran hombres o mujeres, como para castigar y penar a los que sin haber efectuado el examen, se atrevieran a usar de dicho oficio. Delegación que abarca sus dos funciones; una, en el aspecto judicial, como alcalde, para poder juzgar, embargar, condenar y cobrar las caloñas correspondientes a su oficio; por otro, a percibir los salarios y derechos propios de su oficio de examinador mayor. La categoria e independencia que se intenta proporcionar a la institución se manifiesta también en la disposición de que las sentencias de los alcaldes mayores no tuvieran otra apelación posible que ante el rey y en plazo de quince días.

Pero en el reino de Murcia, lo mismo que en otros reinos castellanos. no tendría efectividad este ordenamiento pues, precisamente en el periodo de mayor intervención de la Monarquía en la vida concejil, en la década de 1430 a 1439, cuando don Alvaro gobierna sin oposición y, como secuela suya, el adelantado Alfonso Yáñez Fajardo en el reino de Murcia. es posible valorar a tenor de las noticias que los documentos nos proporcionan el más bajo nivel científico en la asistencia médica a los vecinos de Murcia. No llega a su territorio ningún delegado de los alcaldes mayores y, por otra parte, Fajardo, celoso de cualquier innovación y reacio a cualquier variación, se opondría a todo cambio que en alguna forma pudiera afectar a su omnímodo poder y control del adelantamiento (8).

En la primera década del reinado de Enrique IV, cuando se precisa un gradual afianzamiento del poder real en las ciudades merced a la enérgica labor que llevan a cabo corregidores y asistentes, antes que la rebelión nobiliaria produjera la regresión y provocara la guerra civil, se lleva a efecto una práctica innovación digna de su adecuada valoración. Se trata del establecimiento de un control y vigilancia en el ejercicio de

(8) Chinchilla anota la alcaldia mayor de Juan Alfonso Chirino, físico de Juan Il y "su alcalde y examinador mayor de los físicos y zirugianos de sus reinos", según reza en la 2.* edic. de su Tratado llamado menor dasio de medicina..." fo Toledo, 1513, aunque escries en Sevilla, 1447 (Chinchilla, Anales, I, 90). De Chirino no exite mención alguna en las actas concejiles murcianas. (Vid. mmbién a González Palencia, Angel, Alonso Cbirino, médico de Juan If y padro do Mosén Diego de Valera, Bol. Bibl. Menéndez Pelayo, Santander, 1924, VI, 42.62). 
la Cirugía en forma similar a la que se prestaba en otros oficios, en que sin llegar a hablar o pensar en agremiación, si una vía paralela.

En 1461 el asistente Pedro de Castro, con plena aceptación concejil, 'designó a maestre Benito López de Pulido y a Juan de Merlo como veedores de los cirujanos. Les tomó juramento ante los regidores de que usarian bien de su oficio "guardaran su justiçia a cada una de las partes que ante ellos e a su juizio vinieren", y que no lo dejarian de hacer por ninguna causa ni razón. Al día siguiente se hizo público en la ciudad mediante el siguiente pregón; "Mandan los señores asystente e conçejo, alcaldes, alguazil, regidores, cavalleros, escuderos, ofiçiales e omes buenos de la muy noble çibdad de Murçia que ningunos çurujanos nin otras qualesquier personas, asy vezinos como estrangeros, non sean osados de usar en esta çibdad ni en su termino de arte de çurugia syn primeramente mostrar los recabdos que tienen de como son exsaminados para usar del dicho ofiçio a maestre Benito e a Juan de Merlo, veedores puestos por el dicho asystente e conçejo en el dicho ofiçio de çurugia, en pena a cada uno de sevsçientos maravedis, la terçia parte para el acusador, e la otra parte para los juezes secutores desta çibdat e la otra terçia parte para los dichos veedores, e porque lo sepan todos mandanlo asy apregonar". No tenemos constancia de su continuidad, aunque parece que practicamente se mantendria así hasta que los Reyes Católicos establecen definitivamente el protomedicato.

En otro orden de cosas y en fecha cercana destacan las eficaces medidas tendentes a depurar y sanear el ejercicio de la Medicina, como es la restauración de una vieja ordenanza en que se prohibía a los físicos tener medicinas en sus casas para la venta "ni para sí mismos", bajo ciertas penas. Forma de que sólo pudieran despacharlas y fabricarlas los boticarios y de controlar así sus hechuras, calidades y precios.

Pero en 1463 algunos físicos "agora de presente se atreven a fazerse boticarios", vendiendo en sus casas las medicinas. Las medidas concejiles fueron rápidas y eficaces. En primer lugar reiterar la prohibición, encargando a un regidor de su vigilancia y penalización, con el beneficio de un tercio de la multa que impusiera como estímulo para el cumpli- 
miento de su función. En segundo lugar la exigencia de que los médicos extendieran las oportunas recetas: "que den al enfermo çedula de las medeçinas que han menester para que las conpren do quiera quisieren"; a lo que se agrega la prohibición a los físicos de tomar dinero de los enfermos para comprarles las medicinas, ni tampoco "señalen boticario al enfermo donde las conpre"; por último, pena a los boticarios que hicieran sociedad, "conpanaa", con los físicos. Diferenciación de profesiones, vigilancia y exigencias en beneficio del enfermo, que señalan un propósito de buen obrar y del bien común, pero que no iba a tener plena vigencia, por cuanto muy pronto cambiarian las circunstancias y los hombres que gobernaban la ciudad.

La repetición de prohibiciones indica su incumplimiento. Ya avanzado el reinado de los Reyes Católicos, en 1485, encontramos otro acuerdo concejil con igual significado: "Ordenaron e mandaron que los fisicos que tienen fijos boticarios non tomen las medeçinas en las tiendas de sus fijos, so pena de ser privados de los ofiçios ellos e los dichos sus fijos". 


\section{EL DOCTOR DIEGO RODRIGUEZ, ALCALDE Y EXAMINADOR MAYOR DE LOS CIRUJANOS DE CASTILLA}

Cuando en junio de 1420 lleva a cabo Juan II la designación de dos alcaldes y examinadores mayores de los físicos de toda Castilla y de otros dos para los cirujanos, el que parece tener mayor personalidad de los cuatro y ocupa lugar preferente es el Dr. Diego Rodríguez.

Algo más sabemos, pues en la carta de nombramiento del Dr. Diego Rodríguez como alcalde mayor de los cirujanos conjuntamente con maestre Pedro de Avila, cirujano del rey, nos proporciona un primer paso de avance. Diego Rodríguez se intitula "alcalde e exsaminador mayor de todos los çurugianos", pero antes se dice Doctor de Medicina, lo que supone estudios universitarios, y "fisico de nuestro señor el rey", lo que deja bien de manifiesto que él era médico, aunque su nuevo cargo fuera para conocer la pericia y otorgar las correspondientes licencias a cuantos cirujanos quisieran ejercer legalmente su profesión. Quien realmente era cirujano fue su compañero en la jefatura maestre Pedro de Avila.

Alcaldía que continuaba disfrutando en 28 de diciembre de 1421, ya que en esta fecha otorgaba poder y delegaba en el Bachiller Francisco López para que pudiera inspeccionar los títulos de los cirujanos y examinar a los que aspiraran a serlo en el arzobispado de Tóledo y obispados de Jaén, Cartagena y Cuenca. Continuidad en el cargo y una nota conjunta que bien pudiera ser útil, ya que entre los testigos presenciales a la concesión de poderes, junto a Rodrigo, criado de "Didacus Roderici Medeçine Doctor", aparece un Diego Rodríguez, Bachiller de Medicina que, naturalmente, suponemos hijo suyo: nombre, apellido, oficio, titulo de Bachiller, y ser uno de los integraban su equipo no parecen indicar otra cosa (1).

Dieciocho años más tarde el Dr. Diego Rodríguez seguía desempeñando la alcaldía mayor de los médicos de Castilla, si bien se denunciaba publicamente su actuación por la forma como se hacían los exámenes y las licencias que se concedían a personas que se consideraban

(1) Apéndice, Doc. IV. 
inhábiles, hasta el extremo de que los procuradores expresaron su queja al monarca en la reunión de las Cortes de Madrigal de 1438 (2).

También puede referirse a él la mención que Enrique IV efectuaba en una carta y posterior privilegio rodado otorgando la condición de hidalgo al bachiller Gonzalo Rodríguez de Santa Cruz, al indicar que su hermano, el Dr. Diego Rodríguez había recibido escudo de armas de Juan II. Si es así, si es éste al que hace referencia la carta enriqueña, y no el otro Diego Rodriguez de Valladolid, Dr. en Leyes, con el que intenta identificarlo el profesor Benito Ruano, al que debemos estas noticias (3), entonces podemos establecer una continuidad familiar, que si no es en el desempeño de la alcaldía mayor de los cirujanos, si por lo menos en el servicio y adscripción personal a la realeza, toda vez que Enrique IV le menciona como su médico y valora igualmente los servicios prestados a su padre (4).

¿Cabe, en cambio, buscar en este precedente de alcaldía mayor del Dr. Diego Rodríguez, la sucesión y parentesco con el Dr. Juan Rodríguez de Toledo? De éste sabemos que era Catedrático de Medicina del Estudio de Valladolid cuando en unión de otros compañeros fue elevado al protomedicato por los Reyes Católicos en 30 de marzo de 1477. El apellido Rodriguez, la naturaleza toledana que parece deducirse de ambos alcaldes mayores, el común ejercicio de este oficio e incluso la proximidad cronológica, autoriza a establecer este hipotético parentesco, que queda, como tantas otras cosas, sujeto a su posterior confirmación o rectificación, cuando nueva documentación, o bibliografía por mí no conocida, permita esclarecer algo mejor sus respectivas personalidades y lograr su adecuada identificación.

(2) A lo que respondió Juan II que mandaria ver "las cartas que los dotores Diego Rodriguez e maestro Martín, mis físicos, de mi tienen..." Cortes de León y Cassilla, III, pág. 318 , pet. 8 .

(3) Benito Ruano, Eloy. Tres notas bisfórico-médicas. Cuadernos de Historia de la Medicina Española, IX, Salamanca, 1970, separata, pág. 10.

(4) No desechamos la posibilidad de que este Diego Rodríguez pudiera ser hijo del primer alcalde, e incluso identificarlo con ese Diego Rodriguez, bachiller en Medicina que en 1421 firmaba como testigo la concesión de poderes que el De. Diego Rodríguez otorgaba al Bachiller Francisco López. 


\section{LOS MEDICOS CRISTIANOS}

Pocos son los nombres, porque escasos son los cristianos que ejercen la Medicina en Murcia en esta centuria, y aun su número puede reducirse, ya que siempre queda la duda de si alguno de ellos era converso. Si hay un hecho cierto y es que de procedencia castellana pocos son los nombres que se encuentran mencionados en las Actas capitulares y aun en alguno de ellos no es segura su identificación, toda vez que facilmente puede afiliarse a un origen oriolano. Porque es de Orihuela en su mayor parte o en su totalidad, desde donde llegan a Murcia en el transcurso de estos siglos (1). Con una afianzada tradición, con mayores posibilidades de estudio y una personalidad científica mas acusada, Orihuela cuenta con un selecto número de médicos, alguno de los cuales acude sin inconveniente a Murcia a evacuar consulta o quedan en ella durante tiempo más o menos largo pues los ofrecimientos económicos son atractivos y las amistades poderosas.

Por otra parte la continuidad de los judios, pues, pese a las leyes restrictivas, no existe intolerancia ni agresividad contra ellos, que impide también el aumento de médicos cristianos en la ciudad. La falta de escuelas, tradición y pocas posibilidades económicas que encuentran son factores que suman también a la hora de hacer el recuento de las causas que motivan el escaso número de médicos y cirujanos cristianos en estos años.

Sabemos, por ejemplo, que en 1406 llegaba a Murcia el cirujano Pedro Martínez, quien efectuó las diligencias necesarias para avecinarse y disfrutar del privilegio de franqueza por diez años, otorgado por Juan I con el propósito de incrementar la población ciudana. Pero no volvemos a tener noticia alguna de él, lo que nos hace pensar que su estancia no fue duradera. Algo semejante sucede con el herbolario Domingo Juan, que llega el mismo año y también procede de Valencia y con el

(1) Tal, la autorización de Felipe IJ para que el Dr. Pedro Bives se desplazara a Murcia por la necesidad de su especialización en Urología, (Torres Fontes, Especialistas Médicos on ol siglo XVI, Correo Erudito, XVI, 1942). 
propósito de acogerse al privilegio de Juan I. Tampoco volvemos a saber nada de él, lo que parece indicativo de la brevedad de su estancia, imposibilitado de hacer competencia a la grey hebraica, o bien que, hombre de escasa talla, volvió a oscurecerse en el anonimato de los que viven, trabajan y mueren sin dejar huella perdurable de su paso.

En los años 1416 y 1420 puede valorarse los efectos de una renovación, o por mejor decir, representación personal de las nuevas promociones médicas, que se manifiesta con la presencia de dos bachilleres en Medicina. Títulos que señalan unos estudios mas elevados y las justas esperanzas de lograr situarse en un puesto destacado en la vida ciudadana, a tenor de su categoría y conocimientos. Mas aún por cuanto que en 1420 promulgaba Juan II su disposición creando las alcaldías mayores de físicos y cirujanos, con el loable propósito de purificar y mejorar la asistencia médica en las ciudades castellanas.

No iba a ser así. Lasi costumbres no se cambian en un día y la confianza en determinadas personas no se sustituye rápidamente por la novedad de un título o por unas exigencias fáciles de eludir. $\mathrm{Y}$ más aún cuando lo que se pone en juego es la propia salud o la vida de algún familiar. Y la superstición, pues la larga relación que de ellas se hace en la prohibitiva disposición de don Fernando de Antequera en la menor edad de Juan II, evita más amplio comentario. A lo que hay que añadir el período histórico en que tiene lugar, cuando comienza la pugna entre los infantes de Aragón y don Alvaro de Luna.

De uno de ellos llamado Diego Alfonso, titulado Bachiller en el arte de la Medicina, solo sabemos su presencia en el tribunal que juzgó la suficiencia en 1419 de un aspirante a boticario. Del otro, maestre Jaime Candells, que trabaja en Murcia durante algunos años, tenemos más datos. Llegó en el momento preciso, pues habiéndose ausentado, sin despedirse, el converso maestro Gonzalo, al que la Ciudad gratificaba con mil maravedis anuales para que residiera en ella, "la çibdat estava menguada de físicos, que los non avia ni podía alcançar, e que los paçientes e enfermos que en la dicha çibdat estavan, peligravan muchos dellos por mengua de físicos". Fue entonces, dice el acuerdo, cuando unos regido-

\section{4}


res dijeron a los otros que había llegado a Murcia maestre Jaime Candells, Bachiller en Medicina, y que estaba dispuesto a permanecer en ella si el concejo "le fazia alguna merçed e ayuda con que el biviese en ella". Testimoniada su competencia por algunos de los regidores, hubo inmediato acuerdo de concederle la misma gratificación que hasta entonces se había abonado a maestre Gonzalo (2).

Después, en los años siguientes, lo vemos intervenir como uno más, sin distinción aparente, con los doctores en Filosofía y Teología y físicos y cirujanos judios en los tribunales que designaba el concejo para juzgar la capacidad y conocimientos de quienes aspiraban a ejercer alguna de estas profesiones en la ciudad. Este mismo acompañamiento y equiparación a los especialistas judios se precisa igualmente en la relación de gratificaciones que anualmente concedían los regidores a físicos y cirujanos para asegurar su permanencia en la capital (3).

Hasta 1456 en que se contratan los servicios del doctor Jaime de $\mathrm{Li}$ miñana, es posible advertir otra curva descendente en la participación de médicos cristianos en la vida local. Tanto Jaime de. Limiñana como Rodrigo de Loazes más tarde, son figuras señeras en la Medicina murciana de la segunda mitad del siglo XV, ambos oriolanos y con los que puede precisarse una evidente elevación del nivel científico, acorde con el que en el aspeto social y económico se registra al mismo tiempo.

El descenso en número y calidad que se precisa en los últimos años de la década 1420-30, no sería del todo aventurado explicarlo como una de las consecuencias que se producen con la expulsión de los infantes de Aragón y consiguientes hostilidades que se mantienen en la frontera murciano-oriolana. Lo que puede explicar también el que durante más de veinticinco años no aparezca en Murcia ninguna figura de prestigio en la clase médica.

Otra de las manifestaciones de la regresión que se valora en el transcurso de los siguientes años del reinado de Juan II son' las autorizaciones

(2) En 18.VII-1416.

(3) Del cirujano Alvar Martínez solo sabemos que en 1418 vivía en la parroquia de San Bartolomé y que gozaba de la condición social do hidalguia, (Torres Fontes, Los bidalgos murcianos en el jiglo XV, Anales de la Universidad de Murcia, vol. XXII, n. 1-2, 1964, fol. 19). 
concejiles a determinadas personas, cuyos conocimientos y aptitudes se reconocían públicamente como de inferior categoría, para el desempeño de oficios superiores. Son aquellos que no obstante la posibilidad de efectuar el examen que les facilitara el reconocimiento de su pericia y por tanto les facultara para ejercer su profesión con entera libertad, no se atreven a realizarlo. Lo que supone reconocimiento personal de su insuficiencia y falta de base para salir airosos de las pruebas que pudie. ran exigirseles. Pero tampoco se corforman con mantenerse en el lugar que por sus conocimientos les pertenecía.

Uno de ellos era maestre Jaime Pastor, físico, que por entonces solicitaba del concejo se le adelantara la gratificación del año siguiente "para ayuda a mercar una mula en que andoviese a vesytar la gente por la çibdat". Fue atendida esta petición y dos años después tuvo el concejo el acierto de designar un médico para pobres. Unos regidores expusieron a sus compañeros que en muchas ciudades de Castilla y Aragón había cirujanos para curar a los pobres de sus llagas sin dineros y "esta çibdad está desfalleçida e los pobres pereçen por mengua de dicho çurujano". Hubo unanimidad en la adopción del acuerdo de que se contratara un cirujano y se le señalara salario a costa del erario municipal. El designado fue maestre Alfonso de Librilla, a quien consideraron suficiente y hombre bueno, por lo que se le fijaron doscientos maravedis anuales. Cantidad que permite deducir los escasos conocimientos que debía tener maestro Alfonso.

Abundaba el intrusismo y los regidores tuvieron que poner coto a los más audaces que se entrometían a prácticas para las que no estaban capacitados. En este mismo año 1430 se prohibió a doña Estefanía, esposa de Ferrando, que ejerciera de Medicina y se limitara a su oficio, a "las madrigas de las mugeres", notificándole también que no diera purgas ni efectuara sangrías a ninguna persona bajo pena de seiscientos maravedis. No era ella sola porque "este mismo vedamiento fazen a todas las otras mugeres".

Estos casos no son exclusivos del reinado de Juan II, porque se repiten en todas las épocas y en todos los reinados. Lo que sucede es que 
en este período son más abundantes. Otro, como ejemplo en el reinado de Enrique IV, es cuando en 1468 hubo denuncia formal contra los abusos de Garcerán, ensalmador, que aparte de su especialidad en roturas y dislocaciones óseas, ejercía de cirujano, no sabiendo "cosa alguna de aquella arte, por lo qual es gran cargo de conçiençia e peligro para las personas que cura". Por ello le prohibieron trabajar como cirujano en tanto que no efectuara su examen ante el concejo y en presencia de maestros físicos y cirujanos. No obstante, siendo cierta su habilidad como ensalmador, le autorizaron a continuar en su oficio de "conponer fuesos". Lo contrario que a las mujeres, porque en 1450 por orden del corregidor Diego López Portocarrero se hizo pregón público de que "mugeres algunas de qualquier ley, estado o condiçion que sean, non sean osadas de ensalmar, so pena que estaran diez dias en la cadena".

La carencia de buenos médicos obligó a contratar en 1450 a un doctor en Medicina, aunque el salario que se convino fue mucho mas elevado de lo que hasta entonces se había acostumbrado. Probablemente el Dr. Pardo procedía de Orihuela, pues la gestión concejil se encaminó a la busca de un buen médico, un "bien çiente en la arte de la dicha Medeçina", y esto solo lo encontraba en Orihuela. La oferta era la de abonarle lo que "el entendiese que razonablemente deviese aver", siempre que se estableciera en la Ciudad de forma permanente. Respondió afirmativamente el Dr. Pardo, manifestando que atendía tanto a la solicitud concejil, como "por el e los suyos donde el viene e sus amigos ser naturales desta çibdad". Se convino un salario anual de setenta florines, equivalentes al cambio oficial a tres mil quinientos setenta maravedís.

Otros nombres de físicos y cirujanos cristianos surgen en el transcurso de los años siguientes, pero su escueta mención, una o dos veces, y en actos sin transcendencia médica, reduce forzosamente su indicación a la inclusión de sus nombres en esta relación $y$, quizá en algún caso, como fecha de referencia para un posterior hallazgo o posible identificación de quienes para nosotros no tienen por ahora otro alcance.

Son Fernando Manuel en 1430; el bachiller Juan Albaredes, físico y cirujano, a quien en 1453 se le abonaban dieciseis florines corrientes, 
equivalentes a ochocientos dieciseis maravedís, para el pago del alquiler de las casas en que vivía; el cirujano maestre Diego, que en 1454 lograba exención de velas y rondas, pues había expuesto al concejo que "non podia soportar tanto trabajo" y pensaba en abandonar la ciudad; calificado de buen cirujano y por interesar sus servicios, no hubo oposición en aceptar su demanda; también era cirujano Juan de León, fiador en 1459 de un carnicero y testigo en 1466 con maestre Benito en la operaración realizada por el cirujano oriolano Diego Sánchez en la sala concejil.

Vida más intensa y con diversidad de actividades es la de maestre Benito López de Pulido, cirujano, a quien los regidores hicieron "franco e exento de todas las fazenderas de conçejo... por quanto aquel sirve a la dicha çibdad por su persona cada e quando por el dicho conçejo es llamado". Esto sucede en 1459; pero antes, en 1446, titulándose barbero y cirujano solicitaba un solar en la plaza de las Carnicerías para hacer un obrador; se le concedió, aunque en 1449 el concejo revocó la donación; que volvió a conceder en 1456, cuando maestre Benito se titulaba sólo cirujano (4). En 1463 lograba una merced económica, como era la concesión de la nueva pescadería, si bien obligado al exacto cumplimiento de las ordenanzas acabadas de redactar para la venta del pescado; antes, con Juan de Merlo, había sido nombrado veedor de los cirujanos para su vigilancia y control, así como evitar y penar el intrusismo; en 1466 testifica el feliz éxito de Diego Sánchez; en 1459 como “acompañado" o inspector de alcaldes y examinadores de los barberos y flebotomianos. Tanta actividad y tan diversa pudieran inducir a pensar en una ascendencia conversa.

Hay que agregar otro médico que debió gozar de cierto prestigio,

(4) La solicitud de 22-I-1446 era del solar donde habia "quatro pilares donde pudiere fazer un obrador para el dicho su ofiçio". Fue revocada la donación en 24-1II-1449. De nuevo lo solicitó en 27-VII-1456 con objeto de hacer un porche " en lugar donde tiene una barraca de cañas ante sus casas que son en la collación de Santa Catalina, acerca de las , Carneçerias... para en lugar de la dicha barraca pueda fazer un porche con sus pilares" y se le concedió porque "era provechoso en tienpo de aguas estando el dicho porche fecho se podrían acoger en el algunas personas... pero que non lo puedi cerrar ni incorporar a las dichas sus casas". 
que contó con la decidida protección del adelantado Pedro Fajardo y que intentó sin éxito asentarse y vivir por tiempo en Murcia. La débil naturaleza de Fajardo, gravemente enfermo desde su niñez en diversas ocasiones, exigía la proximidad de buenos médicos que pudieran atenderle rápida y eficazmente. $\mathrm{Y}$ nada mejor para quien disponía a su entera voluntad de la dirección del municipio que hacer contratar a sueldo de la ciudad al médico que pudiera serle útil. Por esta causa, procedente de Alicante, llegaba a Murcia a comienzos de 1470 el doctor Martín Jaimes, a quien el concejo asignó un salario de cuatro mil maravedís (5), y al cual, por ruego del mismo adelantado, aceptó el Cabildo catedralicio sustituir al físico judío que les atendía, y concederle por una vez dos mil quinientos maravedís como ayuda económica. Pero continuó la contratación hasta, 22 de diciembre de 1472 , en que, por causas que ignoramos, los canónigos revocaron su gracia y prescindieron de los servicios del doctor Jaimes. Dentro de la brevedad del acuerdo se advierte cierta dureza de expresión, que quizá responda a su negativa a seguir atendiendo los ruegos y solicitudes del adelantado Pedro Fajardo. Porque no parece existir una relación muy cordial entre el adelantado y mosén Jaime de Limañana, que desde 1456 prestaba sus valiosos y muy apreciados servicios en la capital. Todo lo contrario de la estrecha amistad y subordinación que el doctor Rodrigo de Loazes mantuvo desde 1482 con los Fajardo.

Doctor en Medicina, aunque al parecer no ejercía la profesión, ya que dedicó su tiempo y conocimientos a sanear y aumentar las rentas capitulares, fue "Fernando Diaz Carrión, Doctor en Artes y Medicina, alcolyto y Capellán de nuestro Señor el Papa, y Thesorero de la dicha Iglesia". En fecha anterior a diciembre de 1474, "veyendo que no celebraban en ella tantas Missas que bastassen a la devoción del Pueblo... dotó a la Mesa Capitular de la dicha Iglesia de muchos y solemnes e precio-

(5) El acuerdo concejil es de 5.V-1470, y la elevada cantidad se justifica por la falta de de médicos cristianos en la ciudad, y al mismo tiempo condicionándola a traer y tener en la ciudad a su mujer e hijos. 
sos Libros en Theologia, Artes y Medicina, y Derechos Canonico y Civil, y dio ciertas quantias de dinero...".

Figura interesante cuyos títulos denotan a persona de amplia cultura con estudios universitarios y probable estancia en la Sede Pontificia. A la que sólo podemos agregar que debiá gozar de buena posición económica, conforme puede apreciarse por la fundación de diversas capellanías, para las que dispuso de abundantes rentas.

Pero llegamos así al periodo histórico en que gobiernan en Castilla los Reyes Católicos, estudiados por el Dr. Quesada Sanz hace unos años. No obstante los indudables adelantos que experimenta la vida castellana y que se expresan con diversidad de manifestaciones y la observancia de las leyes que los monarcas imponen, persiste la actividad de quienes sin titulación alguna practican la Medicina y Cirugia, aunque la labor del protomedicato fuera reduciendo campo a los abusos e intromisiones. Otra cosa es la continuidad en las ciudades de segundo orden de una deficiente calidad técnica de Medicina y Cirugía, de la carencia de crítica y del exceso de superstición y de ignorancia. 


\section{FISICOS JUDIOS}

La habilidad, sensibilidad, sentido de la oportunidad y cautela, ocul. tas bajo capa de prudencia y humildad cuando era preciso, fueron cualidades que pública y oficialmente se reconocian en Murcia a los judíos en los siglos medievales. Otras muchas más en relación con la religión y economía tenían un sentido peyorativo no siempre justo, pues las actividades de grupos reducidos, capitalistas y usureros, que no beneficiaban directa ni indirectamente al resto de la comunidad, pesaban no obstante sobre todos ellos. Especialmente a la hora de la crisis, donde las distinciones eran imposibles de realizar.

Preámbulo no obligado pero sí para poder afirmar seguidamente que por las garantías que ofrecían en determinados aspectos de la vida, se les permitió y ellos ampliaron su campo de acción, a veces casi en monopolio, a muchos de los oficios que exigían unas condiciones que no todos poseían. Algunos se inclinan a asegurar de que existe, o parecen tener especial predisposición para ello, lo que en realidad es más bien consecuencia y producto de una educación, de la firme conservación de unas tradiciones y de unas costumbres que señalan unas formas de ser, hacer y obrar. Por ello, aunque hubiera cristianos que alcanzaran semejante suficiencia y capacidad, la continuidad ocasionaba la general aceptación en algunas especialidades, siempre alejadas de esfuerzos físicos, que proporcionaba a los judíos un seguro y beneficioso quehacer, al poder ejercer, casi en exclusiva, determinadas actividades profesionales.

Hubo otras en las que, si no estuvieron solos, también lograron alcanzar privilegiada situación y sostener una vida de relación que les permitía libertades y goces que de otra forma no hubieran podido conseguir. Una de ellas fue la Medicina, otra de la boticarios y algo menos en como cirujanos. Unas veces de padres a hijos, otras dentro de la comunidad. los judíos se trasmiten sus saberes, conocimientos y experiencias guardadas celosamente y que no comunican a los cristianos, lo que en princi: pio les proporciona confianza y mayores posibilidades para destacar y lograr eficaces resultados. Experiencia, habilidad, capacidad de adapta- 
ción y paciencia proporcionan a la larga el fruto apetecido. Más aún cuando su escaso número les hacía más valiosos.

Pero la habilidad de la raza judía era múltiple y sagazmente aprovechaban las circunstancias propicias para su seguridad, trabajo, prestigio y obtención de saneados beneficios económicos. Contaban también con la común ayuda que casi forzosamente habían de prestarse dentro de la aljama, puesto que por las dificultades que a todos ellos se le oponía para el logro de sus propósitos, eran mucho mayores que los que pudieran presentársele a cualquier cristiano. Causa por lo que en las horas bajas de las persecuciones aquellos cuya fe no era muy firme buscaran el camino propicio de la conversión.

De cuantos físicos y cirujanos judíos trabajan en Murcia en el transcurso del siglo XV corto es el número de los que podemos dar algo más del nombre, fecha en que nos ha sido posible localizarlo y de algunas de sus actividades. Pero su relación permite al menos obtener una información más amplia que el conciso dato estricto puede en principio proporcionar.

Comenzamos con una de las figuras más destacadas en la clase médica judía durante la primera mitad del siglo XV, como fue Yuçaf Axaques. Era conocido como buen cirujano, con una continuidad y satisfactoria actividad, que le proporcionaron el aprecio general de cristianos y judios. A fines de 1406, cumpliendo disposiciones de Enrique III, el mariscal Fernán García de Herrera, organizaba su hueste para efectuar una incursión en territorio granadino. Con las fuerzas murcianas, que asaltaban y saqueaban Vera en los primeros días de enero de 1407, iba como cirujano militar Yuçaf Axaques. En el combate fue herido el propio mariscal, así como otros muchos "escuderos", los cuales serían atendidos por Yuçaf Axaques con tanta diligencia y cuidado que, vuelta la hueste a la ciudad y hecha relación de la expedición, el concejo adoptó el acuerdo de gratificar con trescientos maravedís del fondo de la cabalgada a Yuçaf Axaques "por el afan que tuvo".

Sabemos que en 1417 le abonaba el concejo mil maravedís anuales como ayuda por el ejercicio de su profesión, y que en 1431 continuaba 
en igual situación, aunque poco tiempo antes hubo dificultades para todos los físicos y cirujanos a causa de los grandes gastos que tuvo el concejo en la guerra con Aragón, y fueron suspendidas sus gratificaciones. Todavía vivia en 1453, siendo uno de los elementos más destacados de la aljama de Murcia. Al parecer, como tantos otros judíos, Yuçaf prestó también atención y tiempo a la recaudación de impuestos, ya que este es el nombre de un arrendador de las alcabalas del pan y del vino. Lo que no es de extrañar, pues familiares suyos vivían dedicados exclusivamente a la recaudación de tributos reales y concejiles, si bien en 1409 se menciona a un Mayr Axaques, también cirujano, que participa en el examen como oculista de David Damasto.

Algo semejante sucede con el cirujano Mosé Mayr, a quien vemos acompañando a Alonso Yáñez Fajardo en 1421, cuando con una hueste murciana marchó a la conquista de algunas plazas fuertes del marquesado de Villena. Y Mosé Mayr forma conjuntamente con Yuçaf Axaques la pareja de mayor personalidad y autoridad en la clase médica judía de la década 1420-1430.

También destaca la familia Aventuriel, tanto por una continuada permanencia en la Ciudad -localizamos a uno en el s. XIII - y en el arrendamiento de tributos concejiles o reales, como en su actividad médica. A fines del siglo XIV era Jacob Aventuriel arrendador de la alcabala del pan y vino; su hijo David Aventuriel "el de Uclés", fue un gran financiero y su nieto Samuel, declarándose "sabidor en las artes de Lógica, Filosofía y Medicina", lograba carta de aprobación como físico en 1428, ante un tribunal integrado por el doctor fray Juan, prior de Santo Domingo, doctor fray Diego, guardián de San Francisco y "ciertos bachilleres y maestros que allí fueron convocados" (1).

Mucho más tarde, en 1462, cuando todavía el corregidor Pedro de Castro mantenía el orden y la justicia en la ciudad, solicitaba avecindarse en ella maestre Isaac Aventuriel, físico. Manifestó que procedía de Teruel y que había decidido establecerse en Murcia, por lo que solicita-

(1) Publicada en Torres Fontes, Los judios murcianos en el reinado de Jwan II, MurgetaDa, 1965, págs. 32-3. 
ba que le admitieran y recibiesen como a vecino. Su padre Samuel Aventuriel, que seguía ejerciendo como físico en la ciudad, fue su fiador de que cumpliria los diez años de permanencia a que se obligaba al avecindarse.

Otra de las familias arraigadas en la judería murciana y en la que puede precisarse su continuidad en la práctica de la Cirugía fue la de Abserga. Moseh Abserga "desde el año que pasó de mill e quatroçientos a quinze le fueron asentados e mandados pagar por el dicho conçejo de salario mill e quinientos maravedis e non le fueron pagados". Esto se afirmó y así se hizo constar en las actas concejiles de 1462, por cuanto corregidor y concejo, reconociendo sus excelentes servicios y porque maestre Moseh "por ser viejo e venido en pobreza" necesitaba su ayuda, consideraron que era justo y obligado proporcionarsela. El acuerdo fue el de concederle una subvención anual de quinientos maravedis; pensión que fue aumentada a mil quinientos en 1468 en un nuevo acto de reconocimiento de su valiosos servicios. Sus hijos, Yuçaf en 22 de diciembre de 1464, y David en 14 de septiembre de 1465 (2), fueron examinados por el doctor Jaime de Limiñana y declarados aptos para el ejercicio de la Cirugía, logrando la autorización municipal y correspondiente carta de examen.

La continuidad de unos y el puesto destacado que otros ocupan en la vida de relación ciudadana, e incluso la larga vida de muchos de ellos. que en algún caso puede calificarse de longevidad dada la media normal entonces existente, se contrapone a la de otros judíos que no logran nombradía, mueren pronto o su permanencia es corta al marchar a otras tierras en busca de mejores horizontes.

Uno de estos fue maestro Jacobo, cirujano, procedente de Salamanca, que solicitó ser examinado para poder ejercer en Murcia y su reino. Obtuvo licencia concejil en 29 de junio de 1406 y se le expidió carta acreditativa de su examen, pero su nombre no vuelve a mencionarse posteriormente por ningún motivo. Algo semejante ocurre con David Damasto, que se presentó ante los regidores con lucido acompañamiento,

(2) Apendice, doc. VI.

\section{4}


entre ellos el cirujano Mayr Axaques, el boticario Cohen y otros cirujanos y físicos. David acreditó ser un buen maestro de "guarescer e sanar dolençias de los ojos", y por ello no tuvo dificultades para lograr su aprobación. Pero había verdadero interés en que se estableciera en la ciudad. pues, según declararon algunos físicos judíos, por ser mozo quería ir a otras partes, lo que dio lugar a que, reconociendo su valía y necesidad, el concejo le asignara en tanto que permaneciera en Murcia una soldada de seiscientos maravedís. Tampoco se hace referencia posteriormente de su persona, por lo que podemos deducir que su impaciencia juvenil le llevaria a proseguir su ambicioso caminar a otras partes (3).

Un físico que permanece y logra asignación anual del concejo, igual a la que se abonaba a Yuçaf Axaques y Moseh Mayr, fue Moseh Abenbay, quien se examina en 1417 y continuaba al servicio del concejo en 1430. También son escasas las referencias que nos quedan de Yuçaf Abenaex, a quien localizamos en 1439 y con triple dedicación : boticario, cirujano y encuadernador. Menos aún de Zulemán Abenacox, ya que sólo sabemos que era físico y que en 1432 cobraba quinientos maravedís de salario, esto es, trescientos menos de los que se abonaban en la misma fecha a sus compañeros.

En 1449 obtiene título acreditativo de su suficiencia maestre León, quien se declaraba docto en Lógica, Filosofía, Astrología y "arte de la $\mathrm{Me}$ dicina"; por ello en su examen intervienen varios franciscanos y bachilleres, y, sin duda, versó más de Filosofía que de ciencia médica; es probable que sea el mismo que un Rabí León que ejercía como físico en la Ciudad en 1488.

No parece que la presencia en Murcia'de un doctor en Medicina cristiano, y, con la autoridad que Jaime de Liminana tuvo, más las reiteradas prohibiciones que se hace a los judíos, disminuyera mucho su actividad. Sin duda estos físicos y cirujanos no universitarios y de una raza menospreciada pública y oficialmente, se encontrarían en muchos momentos en situaciones condicionadas, toda vez que conforme ley su actividad se limita al ejercicio de su profesión en la aljama y con cierta benevolen-

(3) Apéndice, doc. II. 
cia entre las distintas clases sociales cristianas. Si bien aumenta considerablemente en las fases de epidemias, porque entonces sus servicios son imprescindibles para toda la población y no se vacila en solicitar su ayuda y cooperación.

Pero tampoco estas limitaciones pueden entenderse como inconmovibles fronteras, pues la repetición de prohibiciones es síntoma de que no existen impedimentos nada más que en momentos críticos o en períodos de crisis. Una decisión del Cabildo catedralicio en 1470, al aceptar el ruego del adelantado Pedro Fajardo para que diera salario a un médico recien llegado de Alicante, permite conocer un hecho que a mayor altura podemos verlo en reyes y prelados, y es que canónigos y beneficiados habían estado asistidos por un físico judío, pues el acuerdo que adoptan es el de que "era preferible tener un físico cristiano que non judío". Lo que no puede extrañar, pues cuando en 1478 se renueva el acuerda de que "ningun judío use ofiçio de física ni de cirugía sin ser examinado, so pena de diez mill maravedís para el arca de la Hermandad, pero que pueda curar de ojos", se manifiesta indirectamente que los físicos judíos seguían prestando sus servicios a la población cristiana, pese a todas las prohibiciones e incluso que lo hacían sin haber obtenido licencia municipal mediante el oportuno examen en la corte concejil.

$Y$ cuando la necesidad apremia se olvidan leyes $y$ acuerdos, pues incluso en años en que la Inquisición no sólo ponía orden espiritual entre los bautizados cristianos, sino que también forzaba a una mayor separación de los judios, y por orden de los Reyes el visitador Juan de la $\mathrm{Hoz}$ delimitaba el recinto de la judería y obligaba a levantar altos muros, cerrar calles y reducir espacios, los regidores nombraban cirujano del municipio a Yuçaf Axaraque, tanto por gozar fama de buen cirujano, como en atención a que su padre, ya fallecido, lo había sido durante muchos años; y $\tan$ bien lo hizo que los regidores no dudaron en franquearlo de todas las "fazenderas concejiles" para todos los días de su vida, dán. dole testimonio por escrito de su exención.

Hechos, nombres y acuerdos que reafirman esta indudable e ininterrumpida asistencia de los físicos y cirujanos judíos al servicio de la ciu- 
dad y del municipio, y ello explica que si en 1488 el concejo vuelve a prohibir que los judíos pudieran ser boticarios, tres años más tarde, en 23 de abril de 1491, - a un paso ya de la expulsión-, los regidores designaran junto al Dr. Loazes a Abel Rabí para que "vean e exsaminen los botycarios desta çibdad e las melezinas que tienen, e sy fallaren que son malas, se las derramen" (4).

La expulsión rompería esta línea ininterrumpida que secularmente habian matenido los físicos y cirujanos judíos en Murcia. A la hora de valorar su aportación, el balance en todos los aspectos es favorable. Tuvieron buenos amigos y hasta el último momento los podemos ver trabajar en sus diminutos establecimientos en la plaza de Santa Catalina, la plaza mayor concejil, en abierta convivencia con los regidores que allí acudían antes de las sesiones o al terminar sus reuniones en la cámara municipal. Y mayor acogida aun tuvieron los físicos y cirujanos, porque junto a su necesidad, la conversación y el trato frecuente fomentaba la amistad. Pero la fecha de 1492 iba a ofrecer un duro dilema. Conversión o emigración. El problema ahora alcanza otras dimensiones y solo tres soluciones.

(4) En 1489 se registra el paso, camino de Zaragoza de los fisicos judíos maestre Izmel Bendehud y msestre Meçi, con su acompañamiento de mozos y bestias. Manifestaron cada uno ser portadores de cinco piezas de oro y de cuatro reales castellanos. Se les dió el correspondiente albalá. 


\section{LOS CONVERSOS -}

Las cruentas persecuciones contra los judíos que se inician en Sevilla en 1391 y que rápidamente se extienden por toda la Península, darian lugar a que muchos de ellos, temerosos de morir asesinados, decidieran recibir el bautismo como medio más prudente para salvar vida y hacienda. A causa de su número, estos judíos conversos forman un tipo nuevo en el orden socio-religioso al que forzosamente se le presta especial atención bajo distintos puntos de vista. Por una parte la de los judíos confesos con anterioridad, cuya conversión, hecha con justificada y probada espontaneidad, les distinguía de los recien bautizados; por otra, la de los propios judíos y la de los cristianos viejos, recelosos por ambos lados del alcance, buena fe $y_{1}$ sinceridad de tan masivo cambio por las causas que lo ocasionaban.

Pero en Murcia no se ofrece este problema inmediatamente, ya que la decidida protección que el obispo don Fernando de Pedrosa presta a los judíos, no sólo permite que la judería sea respetada, sino que proporciona tal seguridad a sus habitantes como para que, por este motivo, a partir de 1391 se acreciente considerablemente su población.

Será unos años más tarde cuando tenga lugar el cambio. Rige la diócesis don Pablo de Santa Maria, converso, y se produce como consecuencia de la presencia de San Vicente Ferrer en Murcia, de su dura y tenaz lucha contra el judaísmo y de la promulgación de unas ordenanzas concejiles que casi imposibilitaba o reducía a un horizonte muy estrecho la actividad de los judios. Fueron inmediatas y numerosas las conversiones, por lo que puede deducirse que en ellas hubo de todo, desde la efectuada con sincera fe, a la de los oportunistas, los que buscaban mejores perspectivas, ya que conocían las posibilidades y formas de vida de los que habían efectuado su conversión en 1391.

Porque es entonces, con la aparición de este nuevo tipo, -el converso- cuando puede advertirse en gran número de ellos un continuado afan de actuar, intervenir, participar $y$ aprovechar las posibilidades que en la vida ciudadana les ofrece su nueva religión. $Y$, dentro de ellas, en 
las especialidades que con anterioridad a su conversión habían tenido y para las que no gozaron de todas las facílidades y prerrogativas que disfrutaban los cristianos.

Tal es el caso de los que ejercían coma físicos y cirujanos. La Ordenanza concejil, dictada por San Vicente Ferrer, prohibía "que ningunt judio nin judia nin moro nin mora non sean osados de usar de cirujanía nin de física nin de botiquería entre los christianos, e que de oy en treynta dias primeros siguientes en adelante non usen dello, e esto porque la çibdat se pueda proveer entretanto. $\mathbf{E}$ otrosí, que ningunt christiano nin christiana non llame por físicos nin cirujanos a judios nin a judias, nin moro nin mora, nin merquen dellos medezinas algunas, so pena de seysçientos maravedis a cada uno por cada vez que fuese sabido para los dichos adarves; la terçia parte para el acusador" (1).

Este plazo prudencial de un mes no deja de ser significativo y tiene doble alcance. Lo es en cuanto presupone la falta de cirujanos y físicos cristianos, toda vez que la autorización para su continuidad por treinta días así parece indicarlo; es plazo también para que cirujanos y físicos judios pudieran sentir la tentación de cambiar de signo religioso y aprovechar las favorables circunstancias que se les ofrecía. Lo mismo sucede con los boticarios, oficio también ampliamente dominado por los judíos y tan unido con sus métodos clínicos.

Un mes más tarde, al confirmar los regentes castellanos la Ordenanza murciana introducían algunas modificaciones, tal como el no incluir en ella a los moros, pero manteniendo la expresa prohibición de que "los dichos judios non sean físicos nin cerujanos de los christianos, porque acaeçe que aunque conosçen, segun arte de Medeçina, que es el paciente de muerte, que lo non dizen porque mueran muchos christianos syn fazer sus ordenanças"; y lo mismo en lo que se refiere a los productos farmaceuticos, al autorizar que "puedan conprar e vender con los christianos, salvo especias e melezinas de cirujanos e de fisicos".

En el plazo de un mes no se encontraron médicos cristianos ni los ju-

(1) Torres Fontes, Juan, Moros, judíos y convorsos en la regencio de don Fernando de Antequera, C. H. E., Buenos Aires, 1960, 93-4. 
díos se convirtieron tan rápidamente como cabía esperar. Entonces, como necesidad apremiante y forzosa de atender, el concejo hubo de autorizar la continuidad de físicos judíos para asistir enfermos cristianos. De ello se quejaba en $\mathbf{3 0}$ de mayo el obrero de los adarves, y denunciaba el hecho, no por celo religioso y afan de salvar a los pecadores en la hora de la muerte para que avisados de su próximo fin tuvieran tiempo de arrepentirse, sino por un móvil mucho más sórdido, como era el económico. Estaba legislado que las penas impuestas a los contraventores de las Ordenanzas se destinaran al arreglo de los adarves, y su encargado Pedro Alonso de Escarramad "obrero de los adarves", presenciaba como los físicos judios seguían practicando impunemente entre cristianos.

No contestó el concejo a esta protesta, pero si adoptaba seguidamente el acuerdo de facultar a su jurado clavario para que buscara por cuantas partes creyera conveniente físicos cristianos y los contratara a sueldo del Municipio. Lo que prueba la veracidad de la denuncia y la escasez de médicos cristianos, el que obligaba al propio concejo a quebrantar su Ordenanza.

La falta de médicos cristianos proporciona una amplia perspectiva a los conversos. No podemos saber su número, nombres $\mathrm{y}$ especialidades, pero los hubo, aunque no muchos. De cuatro de ellos nos quedan algunas referencias. En 25 de junio de 1412 maestre Manuel, oculista, o físico de los ojos como el mismo se denomina, reclama ante los regidores con razonada exposición. Se había convertido a la fe católica "por salvar su ánima", lo que le ocasionó un grave perjuicio, ya que con anterioridad, siendo judío, el concejo le abonaba cuatrocientos maravedís anuales de salario, al mismo tiempo que su aljama le ayudaba también económicamente. Confeso, los judios no querian saber nada de él y con los cristianos ganaba menos. Eli concejo hizo lo que debía y fue acordar abonarle, ahora como cristiano, cuatrocientos maravedís de salario por el ejercicio de su profesión.

En 5 de julio del mismo año quien comparece es maestro Gonzalo, físico, también cristiano nuevo, a quien no daban facilidades para alquilar casa en la ciudad y tenía que permanecer en la suya de la judería, 
donde, por su conversión, no era grata su permanencia; aparte de que las disposiciones reales vedaban a los cristianos vivir entre los judíos. Hubo acuerdo de darle seiscientos maravedís de ayuda para pago del alquiler de una casa fuera del recinto de la judería.

Hombre inquieto y descontento, maestro Gonzalo volvía al año siguiente a presentar nuevo memorial al concejo. Se queja de su deplorable situación económica y anunciaba su decisión de trasladarse a Orihuela si no se le facilitaba ayuda suficiente para mantener la posicion que le correspondía. Al parecer el malhumorado maestre Gonzalo sabía lo que se hacía, pues los regidores tuvieron que prestar forzosa atención a su solicitud, toda vez que no había otro médico cristiano en la ciudad. Lo que motiva el acuerdo de 15 de abril de 1413 elevando a mil maravedís anuales la ayuda municipal.

Antes de que transcurrieran tres años se produjo la ruptura y sin previo aviso maestre Gonzalo abandonó la ciudad: Cuando en 1416 se acuerda designar al Jaime Candells como médico de la ciudad, se le adjudican los mil maravedís que daban a maestre Gonzalo "porque aquel estara en la dicha çibdad regidentemente...", pero habían dejado de pagarlos "por quanto maestre Gonçalo, converso, físico, vezino de esta çibdad se era ydo, non sabian a quales partes...".

Otro de los que procuraron sacar provechosas consecuencias de su conversión fue Alonso Yáñez Cohen. Recién convertido lograba en 4 de abril de 1411 trescientos maravedís en ayuda para pagar. el alquiler de las casas en que vivia. En 2 de mayo obtenía el nombramiento de veedor de los boticarios, ya que era el único cristiano que ejercría tal oficio en la ciudad. Necesariamente debía inspeccionar si las medicinas que se suministraban a los enfermos eran adecuadas, y especialmente a los boticarios judíos, ya que eran los que mejor conocian todo el proceso de fabricación de ungüentos, emplastos y fórmulas ordenadas por los físicos, entre los que, a causa de su escasez, seguían siendo los judíos quienes mayor trabajo tenían atendiendo a toda clase de enfermos sin distinción religiosa o social. De aquí la necesidad y conveniencia de un veedor cristiano, aunque fuera cristiano nuevo. 
Quizá atraido por esta escasez de profesionales, campo vedado oficialmente a los judíos, aparece en Murcia el día 19 de octubre de 1412 maestre Juan, hijo de maestre Paulo, triaquero, que solicitó avecindarse en la ciudad, donde había nacido y en donde queria ejercer su oficio en la misma forma que en tiempos pasados lo había hecho su padre. El concejo no sólo admitió su vecindad, sino que al mismo tiempo le declaraba exento de pechos y tributos concejiles por ser buen maestro de hacer triaca y ser necesarios sus servicios.

En 1417 era el converso Alonso Yáñez Cohen el único boticario que quedaba en la ciudad, que alternaba con otro oficio más productivo como era la recaudación de las alcabalas. No podía atender su oficio y como no quería el concejo recurrir a los judíos, buscó forma de solucionarlo. aunque al parecer no la encontró hasta dos años más tarde. En junio de 1419 era admitido a examen Juan. Montagud, tendero y especiero, al que Diego Alfonso, Bachiller en la arte de Medicina, el veedor Alonso Yáñez, el cirujano maestre Exaques y el físico Moseh, tras las preguntas pertinentes, le hallaron hábil y suficiente, por lo que el concejo le otorgó carta acreditativa para el desempeño de su oficio de boticario.

En los años siguientes se mantiene la insuficiencia de médicos cristianos, por lo que son los físicos judios quienes preponderan casi por completo en las décadas siguientes, con algún que otro físico o Bachiller cristiano. Pero cabe suponer que alguno de estos, que alternan en paridad con los judios y que reciben igual indemnización económica concejil, pudiera tener un origen hebráico, ya que la conversión permitiría a los físicos judíos superar su fase empírica tradicional, la de mantener prudentemente los secretos y conocimientos adquiridos en el seno familiar o junto a otros maestros judíos, y entrar de lleno en el conocimiento científico de la Medicina mediante su estudio en Universidades. $Y$ los conversos son a la hora de la renovación quienes se adelantan a primera línea con propósito decidido de mejorar sus conocimientos para obtener resultados más provechosos en su triple aspecto cientifico, económico y social.

Pero no es fácil su identificación, pues si no existen datos que permi- 
tan siquiera conjeturar su filiación, la simple suposición es siempre insuficiente. De cuantos médicos cristianos hemos abierto la interrogante de su origen, sólo uno proporciona argumentos firmes como para poder sospecharlo. Se trata del doctor Jaime de Limiñana, que desde 1456 es médico oficial de la ciudad de Murcia y en ella ejerce hasta 1482, en que por ignoradas causas vuelve a Orihuela, de donde procedía (2). Las repetidas solicitudes concejiles para que volviera a la ciudad no tuvieron los resultados apetecidos.

Dos hechos justifican nuestra atribución. Es uno el que entre las instrucciones que se formularon al emisario que el municipio murciano enviaba a los Reyes Católicos en 1491, una de ellas decía: "aveys, más, de procurar que el doctor Limiñana sea físico desta çibdad, non enbargante que está inhabilitado de la Santa Ynquisiçión". Lo cual denota, al menos, una mentalidad o creencia no enteramente ortodoxa.

Otro elemento de juicio para una posible explicación de su procedencia es su actitud personal en el orden económico. Comienza cobrando un salario oficial de tres mil maravedís, que en 1478 se había ya elevado a ocho mil, mas otras mil para ayuda en el alquiler de las casas en que vivía, y que al año siguiente alcanza los doce mil maravedís. Cifra elevada para la normal ayuda de costa que concedía el municipio. Lo que significa por un lado el aprecio concejil y ciudadano que debía haber alcanzado por su trato personal y conocimientos científicos y, por otro, su preocupación económica. Otros datos nos confirman este interés tan peculiar por el dinero. En 1477 el doctor Limiñana efectúa un préstamo al concejo para'que éste pudiera atender con urgencia al pago del privilegio de la franqueza. Al año siguiente el concejo le abona 3.300 maravedís. En 1479 los regidores le reconocen una deuda de 24.300 maravedís, de los cuales nueve mil corresponden a su salario del año anterior, doce mil al nuevo sueldo de 1479 y 3.300 a otro préstamo anterior hecho al municipio para que pudiera pagar los caballos que se enviaban a la Hermandad.

(2) Quesada Sanz, Jesús. Algunos aspectos de la Medicina en Murcia durante lo poca de los Reyes Católicos, Murgetana, 6, Murcia, 1954, pág. 76. 
¿Es "desprendimiento con que, más de una vez, socorre al Concejo de su propio peculio", como afirma el Dr. Quesada? Nos parece, por el contrario, que no hay desprendimiento y sí préstamo, con un interés legal, -el diez por ciento- que estaba muy lejos de los niveles que alcanzaban por entonces otros préstamos y que entraban en declarada usura. Pero si el interés era reducido, no dejaba de ser una provechosa operación, pues si no proporcionaba un beneficio económico muy grande, sí lo representaba en cuanto a que por este medio obtenía el agradecimiento concejil, puesto de manifiesto en la elevación de su salario y en el decidido empeño de que continuara ejerciendo su profesión en la ciudad.

Estos hechos: precipitada huída de Murcia, inhabilitación por parte de la Inquisición y sus préstamos económicos al Concejo parecen responder a una misma causa, que nosotros deducimos pudieran proceder de una posible ascendencia judáica del doctor Limiñana. 


\section{UN CIRUJANO GRANADINO}

La continuidad de unos topónimos y de un reducido aunque sonoro vocabulario, así como el de unos usos y costumbres que imaginativamente se asocian con el mundo árabe, dio lugar a que injustificadamente se mantuviera durante siglos un tópico que enmascara territorios y tiempos bajo el común denominador de creación o influencia musulmanas. El examen de una y mil cosas no puede por menos de producir sorpresa, por cuanto la verdad reduce a la mínima expresión cualquier influencia de signo positivo y trascendente que claramente manifieste su procedencia musulmana. Por lo menos esta afirmación es válida en cuanto se refiere al reino de Murcia en los siglos XIII, XIV y XV.

Reducidos a los muy pocos años de la conquista a una serie de morerías, que se distribuyeron por el territorio murciano bajo el amparo de los comendadores de las Ordenes Militares o de los administradores de la Iglesia, su trabajo de la tierra, hierro, cerámica y esparto no fue nunca de calidad, ni excepcional ni siquiera de eficaz rendimiento. $Y$ lejos de ellos cualquier conocimiento superior, científico o espiritual, toda vez que en las estrechas callejuelas del arrabal de la Arrixaca, en la capital, no se reunían en su morería más de quince míseras familias.

De aquí que resulte sorprendente la noticia de un cirujano moro de cierto relieve en la ciudad de Murcia en los comienzos del siglo XV. Pero la sorpresa desaparece cuando conocemos su origen granadino. Aparentemente las relaciones entre castellanos y granadinos, tanto en tiempos de guerra como en los de paz, se reducían a la recepción o envío de emisarios, entrevistas entre los alcaldes mayores de la frontera encargados de reparar errores o de exponer agravios y las visitas, más o menos frecuentes, de los alfaqueques de uno y otro reino en misión de rescate y canje de cautivos.

Poco, muy poco, se sabe de las relaciones mercantiles que se mantuvieron entre ambos reinos, y las que conocemos es más por la legislación que por el comercio mismo. Unas veces son los artículos que se insertan en algunos tratados de paz, en que se especifican las autorizaciones que 
se conceden para el tráfico mercantil; en otras ocasiones por las prohibiciones que se decretan en la exportación de determinados artículos comerciales, lo que implica que se mantenía un intercambio con los productos que no se vedaban; por las multas y embargos impuestos por los alcaldes de sacas, que manifiesta la actividad de los contrabandistas y, tambịén, los arrendamientos y recaudaciones del servicio y medio servicio de lo morisco, que gravaba la exportación castellana al reino de Granada.

En tiempo de paz, aparte de estas relaciones oficiales de emisarios, alfaqueques y mercaderes, existía la posibilidad de que privadamente cualquier castellano, judío o granadino, pudiera trasladarse de un reino a otro. Pero el viaje, pese a la garantía que pudieran ofrecer los tratados de paz o las treguas, o los seguros otorgados por autoridades superiores, era peligroso. El amplio territorio yermo y despoblado a uno y otro lado de la frontera, donde sólo era posible buscar el amparo o ayuda en las fortalezas avanzadas o en las poblaciones más cercanas donde existían guarniciones, no dejaba de ser una aventura. Las acciones de represalia o el bandidaje de quienes vivfan en gran parte del robo, del botín o de la cautivación de indefensos caminantes o pastores en las proximidades de la frontera, no eran fácil de eludir. A otras muchas asechanzas estaban expuestos los viajeros sin escolta o sin valioso salvocontucto, pero no es momento de enumerarlas.

Los documentos concejiles sólo conservan datos y no muy amplios de estas relaciones que podemos calificar de oficiales, pero en algunas ocasiones, aunque sea de forma indirecta, proporcionan nombres y circunstancias de algunos otros o de las motivaciones de su presencia en reino extraño. Sucede así y habría que explicarlo detenidamente, con los granadinos que acudían en peregrinaje al monasterio de San Ginés de la Jara, en las proximidades del Mar Menor. Y otro caso, que es el que aquí queremos dar a conocer, es el que se refiere al cirujano y médico maestre Farach.

Llamado probablemente por algún ciudadano perteneciente al patriciado urbano, conocedor por los alfaqueques de su maestría, y con sal- 
voconducto de Juan Rodriguez de Salamanca, corregidor de Murcia y justicia mayor del reino, procedente de Granada llegaba maestre Farach a Murcia a fines de 1404 o muy en los comienzos de 1405.

En corto espacio de tiempo realizó numerosas intervenciones que probaron su habilidad y competencia. Pero llegó el momento de pensar en regresar al reino de Granada. Fue entonces cuando se conjuntaron los intereses de todos. Apreciada su valía y cuanto podía significar su permanencia en la ciudad, regidores $y$. jurados le instaron a que se quedara en Murcia, garantizándole el ejercicio de su profesión y la seguridad de alcanzar una próspera situación económica. Y a maestre Farach le atrajo el ofrecimiento.

Habiendo llegado en principio a un acuerdo, regidores y jurados, conocedores de que todavía tenía muchas "curas encomendadas" y que si se marchaba "las tales personas estan en condicion de muerte o de ser lisiados", expusieron al corregidor y concejo la conveniencia de contratar sus servicios. Paso previo fue que maestre Farach justificara oficialmente su competencia. Examinado por médicos y cirujanos en la casa de la Corte, y habiendo probado plenamente su suficiencia, el Concejo le otorgó licencia para ejercer su oficio de físico y cirujano en toda la jurisdicción de la ciudad, al mismo tiempo que le señalaron una ayuda oficial de mil maravedís anuales (3). Todo ello condicionado a que se estableciera en Murcia de manera permanente, y la forma de lograrlo fue exigirle que hiciera venir del reino de Granada a su mujer, Fátima, y a sus hijos. Y para facilitarle los primeros gastos, le gratificaron con doscientos maravedís más para el pago de la casa donde había de instalar a su familia.

Sabemos que, gozando de la misma soldada y porque el concejo atendió su queja de que se le abonaban en los plazos convenidos, maestre Farach continuaba viviendo en Murcia a fines de 1406 y seguía prestando sus valiosos servicios.

No hemos encontrado mención alguna de maestre Farach en fechas posteriores. Es posible que este silencio se deba a que reanudada la guerra con Granada maestre Farach volviera oportunamente a su tierra.

(3) Apéndice, doc. I. 


\section{LOS BARBEROS}

En Castilla, al contrario que en Aragón (1), parece existir una clara diferencia y distinta valoración científica del cirujano y del barbero. Por lo menos en el transcurso del siglo XV. El cirujano castellano y al hablar de castellanos incluimos entre ellos a los judíos que vivian en su territorio, logró obtener a fines del siglo XIV el reconocimiento público de una solvencia profesional que gradualmente le fue acercando al físico en sus aspectos social y económico, hasta equipararse con él muy poco después. Y esta equiparación adquiere carácter oficial, superando la proyección concejil hasta entonces vigente, cuando en 1420 se establecen dos alcaldías y examinadores mayores para físicos y cirujanos, sin más diferencias que las estrictamente profesionales, a igual que sucedía con anterioridad en la vida de relación ciudadana.

No ocurre asi con los barberos, pues tienen limitadas sus actividades y señalados los casos en que pueden intervenir. Pero las excepciones son frecuentes en los períodos de crisis monárquica, en los que el poder central no puede ejercer un control directo sobre los municipios, lo que permite que los regidores tengan mayores posibilidades de llevar adelante sus particulares intereses. Por ello las autorizaciones que se conceden a algunos barberos para poder ejercer como cirujanos o su contratación a sueldo del propio municipio, no es otra cosa que el resultado de la influencia de determinadas personas para obtener el beneplácito concejil a sus pretensiones. Lo que no significa por ello que en verdad se valoren los conocimientos científicos del solicitante, sino que los regidores se conforman y aceptan las seguridades que le sofrece su valedor, al que atienden por razones particulares, de favor, afecto o en atención al cargo que desempeña. $O$ lo que es lo mismo, no se valora al aspirante, sí la personalidad de su fiador.

Sucede así con Juan Martínez de Burgos, de profesión barbero, que llegó de Burgos con el decidido propósito de trabajar como barbero, pero

(1) García Ballester, Luis. La cirugla en la Valoncia del siglo XV. Cuadernos de Historia de la Medicina Española, VI, Salamanca, 1967, págs. 155-171. 
dispuesto también a practicar sus conocimientos de Medicina y Cirugía. Hubo una primera negativa concejil a sus pretensiones; a todas ellas. Pero el de Burgos se buscó la influencia todopoderosa de Gonzalo Martínez de Covarrubias, chantre de la Iglesia de Cartagena. Aquí es posible encontrar una relación de paisanaje, toda vez que covarrubiano uno y de Burgos otro, ambos a su vez derivados del eje eclesiástico que se mantiene durante varias décadas entre Murcia y Burgos, cuya iniciación se encuentra en la familia Santa María, de la que fue cabeza don Pablo, obispo de Cartagena primero y después de Burgos, lo mismo que otro de sus elementos más destacados en la segunda mitad de la centuria lo sería el cronista Diego Rodriguez de Almela.

El chantre Martínez de Covarrubias hizo acto de presencia en la reunión concejil de 8 de junio de 1416 y solicitó de los regidores que permitieran a Juan Martínez trabajar en todos los oficios en que se declaraba práctico : barbero, físico y cirujano, pues él respondía de sus conocimientos y eficacia. Ante testimonio tan respetable, sin exigir el acostumbrado examen en la cámara de la casa municipal por otros físicos y cirujanos, los regidores no tuvieron inconveniente en autorizarle para trabajar indistintamente en las tres profesiones que decía conocer (2).

Estas intromisiones y las consiguientes debilidades concejiles fueron causa principal que aconsejó la designación de unos jueces o alcaldes y examinadores mayores para todo el reino castellano. Y cuando en 1420 se establecen en Castilla los alcaldes mayores de médicos y cirujanos, también se crean para barberos y albeitares, con objeto de delimitar funciones, fijar competencias, ordenar el trabajo y obtener garantias y seguridades en la actividad profesional de cada una de ellas, mediante cartas de examen, autorizaciones oficiales o titulos universitarios.

Pese a ello, la política es quien decide con frecuencia el cumplimiento o el olvido de las disposiciones legales. En ella encontramos la explicación de que en 1430, cuando en Murcia habían estado ya a servicio del Concejo dos bachilleres en Medicina y se realizaban exámenes de suficiencia por los físicos y cirujanos contratados por la Ciudad, no sólo se

(2) Apéndice, doc. III. 
sociales más altas del adelantamiento. Gran número de ellas, apenas esbozadas en estos años, puede verse luego plenamente desarrolladas en las dos últimas décadas de esta centuria. Una de sus muestras es este nombramiento de acompañado, precisamente de maestre Benito López de Pulido, que en 1461 sería nombrado también veedor de los cirujanos. Lo que significa que la presencia al frente del municipio de los corregidores permiten que estas funciones de vigilancia y control se ejerzan de forma adecuada $y$, también, que no se conviertan en prebendas sin mas fin que obtener saneados ingresos. Por otra parte, la intervención del cirujano maestre Benito en todo examen de flebotomias garantizaba la rectitud de la prueba y la justa concesión de las licencias que pudieran concederse. 


\section{LA APUESTA DE UN CIRUJANO}

Tanto en el transcurso de los siglos medievales como en las centurias siguientes hubo Murcia de recurrir frecuentemente a la ayuda médica de Orihuela. Esta prestación se ofrecía en el doble aspecto de exigir siempre número suficiente de médicos oriolanos para atender las solicitudes murcianas, como en la calidad de sus especialistas, a veces con novedades en Medicina o Cirugía, que ratificaban la competencia científica de que estaban acreditados los bachilleres y doctores oriolanos.

Numero y calidad que no impedía el que abundaran también los que alardeaban de amplios conocimientos médicos y sólo eran audaces aventureros en busca de fama y dinero. En unos tiempos en que la superstición y la ignorancia se extendían hasta las capas sociales más altas y en que unos someros conocimientos filosóficos solía ser el mayor bagage de muchos de los que se titulaban físicos, las consecuencias de su actividad no podían ser más deficientes.

Pero de vez en cuando surgen hombres que se singularizan por un hecho, que no siempre responde a su profesión habitual, sino a su carácter y forma de ser. Uno de estos' iba a ser el cirujano Diego Sánchez. Debía haber alcanzado cierto prestigio mas allá de la jurisdicción de su ciudad natal, por cuanto el notario Alfonso Palazol solicitó sus servicios y le pidió que se desplazara a Murcia a operar a su mujer. No se trataba de ninguna operación extraordinaria, puesto que el padecimiento de Isabel Pérez, la esposa del notario, era un cáncer de mama y su extirpación no suponía innovaciones técnicas, sino si por la forma en que lo realizaba maestro Diego Sánchez el cáncer no se reproducía. Pero el mismo notario, a la hora de abonar sus honorarios, puso en duda las seguridades que le ofrecía el cirujano, y en la duda exigió de Diego Sánchez prestase fianza respondiendo de la curación de su esposa.

El pleito fue ante el concejo y. los regidores designados para arbitrar solución justa a esta cuestión, buscaron la ayuda y consejo de todos los físicos y cirujanos que había en la ciudad. La resolución adoptada fue la de obligar al cirujano oriolano, antes de que cobrara sus honorarios, a 
dar fiador que respondiera por él' de que en plazo de un año no se reproduciría el mal, pues en este caso habría de devolver la cantidad devengada (1).

Seguro del resultado de la operación y para castigar la incredulidad de Alfonso Palazol, maestro Diego Sánchez aceptó el fallo concejil, pero impuso sus condiciones: ampliar el plazo del año que se le exigía por cuarenta días más, a cambio de que si en este tiempo la dolencia de Isabel Pérez no reaparecía, el notario Palazol le abonara mil maravedís más en compensación a las molestias que le ocasionaba.

Hubo conformidad por ambas partes. Transcurrido el año y algo más de cuarenta días, maestre Diego seguro de su triunfo volvió a Murcia y cobró su apuesta. A lo que añadió una certificación oficial del feliz resultado de su operación.

Pero no fue esto todo, pues su éxito le proporcionó otro caso semejante. A solicitud concejil operó a una vecina de Aledo afectada también de cáncer de mama. Y para disipar dudas efectuó la operación en la sala de juntas del ayuntamiento en presencia de todos los regidores. Un nuevo testimonio concejil, de quienes "a ojo nosotros lo vimos", certificaba su habilidad y competencia (2).

(1) El fallo fue justo y sin duda basado en el Fuero Real que como código supletorio era utilizado en alguna que orra ocasión en Murcia. En la Ley II, tit. XVI, Libro IV, dice: "Si alguin física o Maestro de llagas tomare a alguno en guarda por pleyto que lo sane, e si ante que sea sano de aquella enfermedad muriese, no pueda demandar el jprecio que habie taxado; y esto mesmo sea si puso sanarlo a plazo señalado, e no lo sanó".

(2) Apéndice, doc. VII.

\section{4}




\section{APENDICE}

1405-II-21, Murcia.-Licencia concejil a maestre Farach, moro granadino, físico, para el ejercicio de su profesión. (A. M. M., Actas Capitulares 1404, sesión de 21-II-1405).

Sepan quantos esta carta vieren como nos, el conçejo, cavalleros, escuderos, alcaldes, alguazil, jurados e ofiçiales e omes buenos de la muy noble çibdat de Murçia, con voluntad e otorgamiento de Johan Rodriguez de Salamanca, doctor en Leyes, oydor e referendario de nuestro señor el rey e su corregidor e justiçia mayor en la dicha çibdat e en el su adelantamiento, seyendo ayuntados a conçeio en la camara de la corte de la dicha çibdat segund que lo avemos de uso e de costunbre, otorgamos e conosçemos en buena verdat a vos, maestre Farach, moro de la tierra e señorio del rey de Granada, que por quanto sodes venido aqui a la dicha çibdat con nuestra voluntad e con nuestro seguro porque nos dieron a entender, e es ello asi, que vos sodes buen maestro de arte de çurugia e de fisica e que avedes fecho e fazedes de cada dia muchas buenas curas en la dicha arte de çurugia e de fisica, segund lo mostrastes e avedes mostrado ante nos por testimonios de escrivanos publicos e aun por exsaminacion que de vos maestre Farach fue fecha e reçebida ante nos en el dicho conçejo e doctor por otros sabidores fisicos e çurujanos cristianos e judios sabidores de las dichas artes que a ello fueron por nos mandados llamar el dicho exsamen, vezinos desta çibdad; e otrosi, por quanto nos fue fecha relaçion por pieça de vezinos de la dicha çibdat que vos los aviades curado e sanado de largas e fuertes enfermedades e llagas e naçençias malas que los sobredichos tenian de largos tienpos. E otrosi, por quanto vos, dicho maestre Farach, avedes prometido a nos el dicho conçejo que traheredes e avedes de traher a vuestra muger Fatima e vos venir con vuestra casa a morar e bevir e fazer aqui vezindat en esta dicha çibdad a usar del dicho vuestra ofiçio, por ende, 
por lo que dicho es damos vos liçençia e otoridat para que podades usar e usedes del dicho ofiçio de arte de çurugia e fysyca, segund e en la manera que fasta aqui avedes usado bien e leal e verdaderamente; e por vos fazen ayuda e bien e merçed porque estedes e moredes vos e vuestra muger aqui en esta dicha çibdat e usedes del dicho ofiçio de como sobredicho es, damos vos para que ayades de cada año de nos el dicho conçejo mill maravedis, de tres blancas el maravedi, desta moneda corriente de nuestro señor el rey: los quales mandamos a Remir Sanchez de Madrit, jurado clavario de nos el dicho conçejo, e otros los den e paguen de cada año por terçios del año, en cada terçio lo que y montare, bien e conplidamente en guisa que vos non mengue ende alguna cosa. $E$ en testimonio mandamos vos dar esta nuestra carta, escripta en pargamino e sellada con el sello de tablas de nos el dicho conçejo e signada del signo de Pedro Royz Delgadillo, notario e escrivano de nos el conçejo de la dicha çibdat. Fecho veinte e un dias de febrero, año del nasçimiento del nuestro salvador Jhesuchristo de mill e quatroçientos e çinco años. Testigos Fernando Oller e Johan Ortega de Aviles, vezinos de Murçia.

\section{I}

1409-VI-11, Murcia.-Testimonio concejil del examen y consiguiente autorización para ejercer como físico a David Damasto.

Sepan en como el conçejo, cavalleros, escuderos, alcaldes e alguazil, e jurados e ofiçiales e omes buenos de la muy noble çibdat de Murçia, otorgamos e conosçemos que por quanto vos maestre Davi Damastos sodes buen maestro de sanar dolençia de los ojos segund que antes fue fecha relaçion por çiertos cirujanos e maestros de la dicha çibdad que vos examinaron en la camara de la corte, donde acostunbramos de nos juntar a conçejo, e otrosi, por quanto somos informados de otros vezinos de la dicha çibdat que vos, dicho maestre Davi, que avedes fecho buenas curas en esta dicha çibddat e fazedes de cada dia, e por quanto nos 
lo pediestes que vos queriades fazer que vos diesemos liçençia para ello. Por ende, el día de oy, aviendo visto la relaçion a nos fecha por los dichos cirujanos e otrosi, seyendo enformados por algunos vezinos de la dicha çibdad que avedes fecho buenas curas de la dicha arte, damosvos liçençia e otoridat para que podades usar e usedes del dicho ofiçio de fisica en esta dicha çibdat e en sus huertas e terminos, e mandamos a qualesquier personas que vos non pongan question ni enbargo de la dicha arte, pues vos sodes exsaminado por los dichos maestros, e que usedes della segund que todo buen maestro deve usar. $\mathrm{E}$ porque esto sea firme e non venga en dubda mandamosvos dar esta carta de liçençia e otoridat escripta en pergamino e sellada con el sello de tablas en çera pendiente de nos el dicho conçejo, e signada del signo del nuestro escrivano. Fecha dia e mes e año sobredicho. Testigos Pedro Ingles e Gines Martinez, notarios, vezinos de Murçia.

\section{I I}

1416-VI-8, Murcia.-Licencia y facultad otorgada por el concejo de Murcia a Juan Martinez de Burgos, para poder ejercer como barbero, físico y cirujano.

E por quanto en el dicho conçejo fue dicho e soplicado por Gonçalo de Cuevas Ruvias, chantre de la Yglesia de Cartajena, en como Juan Martinez de Burgos, barvero, era venido a esta çibdat era buen maestro de la dicha arte e de sangrar e aun de arte de Fisica e de Curugia e que a como quier quel dicho Juan Martinez era buen maestro de las dichas artes que le non consentian usar dellas, mas segund le era dicho que le non dexavan usar dellas ni de algunas dellas, e pedia por merçed al dicho conçejo que a su nobleza pluguiese de le dar leçençia al dicho Juan Martinez para que pudiese usar de los dichos ofiçios como el les fazie fe testimonio quel dicho Juan Martinez era muy buen maestro e pertenesçiento para usar de los dichos ofiçios e de cada uno dellos. E el dicho 
conçejo e ofiçiales e omes buenos, oydo lo que dicho es e visto la relaçion a ellos fecha por el dicho Gonçalo Martinez, chantre, dieron liçençia al dicho Juan Martinez de Burgos, barvero, para que pueda usar e use los dichos ofiçios e de cada uno dellos asy en la çibdat de Murçia como en su termino; al qual dieron e otorgaron la dicha liçençia e todo poder conplido para usar de los dichos ofiçios e cada uno dellos segund que todo barvero e fisico e çurujano puede e deve fazer. $\mathrm{E}$ mandaronle dar carta de liçençia.

\section{V}

1421-XII-28, Toledo.-Carta de poder del Dr. Diego Rodriguez, alcalde y examinador mayor de todos los cirujanos, a favor de Francisco Lobez, Bachiller en Medicina, para ejercer dicho oficio en el arzobispado de Toledo y obispados de Jaén, Cartagena y Cuenca.

Sepan quantos esta carta de poder vieren como yo, Diego Rodriguez, doctor en Medeçina, fisico de nuestro señor el rey e su alcalde e exsaminador mayor de todos los çurugianos en todos los regnos e señorios del dicho rey, otorgo e conosco que do todo mi poder conplido a vos, Françisco Lopez, bachiller en Artes e en Medeçina, para que por mi e en mi nonbre seades $\mathrm{mi}_{\mathrm{i}}$ alcalde e exsaminador de todos los çurugianos e çurugianas en todo el arçobispado de Toledo e obispados de Jahen e de Cartajena e de Cuenca de todos aquellos e aquellas que usaren de çurugia, salvo si fueren exsaminados de mi, el dicho doctor Diego Rodriguez o de mi conpañero maestre Pedro de Avila, çurugiano del dicho señor rey, o aquellos a quien vos dieredes liçençia o exsaminaredes. $\mathrm{E}$ los que asy fallaredes que usan del dicho ofiçio de çurugia e non fueren exsaminados como dicho es, fueren ynorantes, que fagades en ellos e en cada uno dellos justiçia asi en los cuerpos como en los algos, e para que podades prendar e prendedes por las penas en que cayeren e para que levedes 
dellos e de cada uno dellos los derechos e salarios segund el dicho señor rey manda por la dicha su carta. E quan conplido poder yo he e el dicho señor rey me da por la dicha su carta para todo lo que dicho es e para cada cosa dello, tal e tan conplido lo do e otorgo a vos, el ditcho Françisco Lopez, bachiller, en tanto quanto con derecho puedo e devo para que podades dar carta de exsamen, e revoco todos los otros poderes que yo di e otorgue sobre aqueste caso e razon. E por esta mi carta digo de parte del dicho señor rey e ruego de la mia a los conçejos e alcaldes e justiçias e regidores e otros qualesquier ofiçiales de las çibdades e villas e lugares del dicho arçobispado e obispados que vos ayuden e anparen a conplir todo lo sobredicho e a cada icosa dello segund quel dicho señor rey ge lo manda por la dicha su carta. $E$ porque es verdat e non venga en dubda, di vos esta mi carta en que escrivi mi nonbre, e por mayor firmeza rogué a Pedro Martínez de Villegas, escrivano de nuestro señor el rey e su notario publico en la su corte e todos los sus regnos, que la signase con su signo.

Fecha en la muy noble çibdat de Toledo, veynte e ocho dias de diziembre, año del nasçimiento del nuestro Salvador Jhesuchristo de mill e quatroçientos e veynte e dos años. Testigos que fueron presentes a todo esto que dicho es, Diego Rodriguez, bachiller en Medeçina, e Juan Alfonso de Cadahalso, vezinos de la dicha çibdat de Toledo, e Andres Martinez, fijo de Pedro Martinez, e Rodrigo, criado del dicho Diego Rodriguez. Didacus Roderiçi Medeçine doctor. E yo el dicho Pedro Martinez de Villegas, escrivano e notario publico del dicho señor rey sobredicho, fuy presente a todo lo que dicho es en uno con los dichos testigos, e de ruego e otorgamiento del dicho Diego Rodriguez, doctor, que en esta carta de poder vi escrivir aqui su nombre, e por ende fize aqui este mío signo a tal en testimonio de verdat. Pedro Martinez, escrivano. 
1450-IV-10, Segovia.-Príncipe D. Enrique nombra como sus barberos mayores a Juan Muñoz y Martín Gutiérrez. En confirmación, ya como rey, en Avila, 15-XI-1455; y poder de éstos a Gonzalo de Toro, como alcalde mayor del reino de Murcia en Segovia, 6-VI-1459. (AMM. Cart. 1453-75, fols. 85-6).

Don Enrique, por la graçia de Dios prínçipe de Asturias, fijo primogenito heredero del muy alto e muy poderoso señor, mi señor e padre el rey don Iohan de Castilla e de Leon, por fazer bien e merçed a vos Iohan Muñoz e a Martin Gutierrez, mis barveros, vezinos de la muy noble çibdad de Segovia, tengo por bien e es mi merçed que seades mis alcaldes e examinadores en todas las mis çibdades e villas e lugares que yo he $e$ tengo e oviere e toviere de aqui adelante, así de christianos como de judios e moros, de qualquier estado e condiçion que sean, así de los que agora son como a los que seran de aqui adelante, que ningund barvero que non pueda poner ni tener tienda nuevamente, ni usar de sangrías ni de arte de la flemotomía sin ser primeramente exsaminados por vos los dichos Iohan Muñoz e Martin Gutierrez, mis barveros, o por qualquier de vos o por aquel o aquellos que vuestro poder para ello oviere, e para que en vuestro logar e en vuestro nombre podades poner e pongades en todas las dichas mis çibdades e villas e lugares alcaldes exsaminadores del dicho ofiçio de barvería e sangrías e arte de flemotomía. E otrosí, mando e tengo por bien que si algunos de los dichos barveros fizieren yerro alguno en el dicha ofiçio, que vosotros o qualquier de vos ge lo podades emendar e corregir e defender que non use dello en aqueIlo que fallaredes que non sea ni es perteneçiente para ello.

E por esta mi carta o por el treslado della signado de escrivano publico mando a todos los barveros sobredichos de todas las dichas mis çibdades e villas e logares e de cada una dellas, que venga ante vos los dichos Iohan Muñoz e Martin Gutierrez, mis barveros, o ante qualquier de vos o ante quien vuestro poder para ello oviere, e quando vos los man- 
daredes llamar e enplazar por algund portero o por vuestra carta de vosotros los sobredichos o de qualquier de vos, o ante aquel o aquellos que vos pusieredes para lo ver e librar so pena de sesenta maravedis a cada uno por cada plazo e llamamiento que les fizieredes e mandaredes fazer para que sepades quales son aquellos que deven usar del dicho ofiçio. $\mathbf{E}$ aquel o aquellos que vos, los dichos Iohan Muñoz e Martin Gutierrez, mis barveros, o qualesquier de vos, fallaren que non son pertenesçientes para usar del dicho ofiçio so pena de la mi merçed e de dos mill maravedis desta moneda corriente que se agora usa e corre a cada uno para la mi camara, e de mill maravedis para vos los dichos Iohan Muñoz e Martin Gutierrez, mis barveros.

E otrosí, es mi merçed e mando que ninguna ni algunas personas o personas que non tovieren tienda ni fueren exsaminados, que non afeyten ni sean osados de afeytar sin liçençia e mandado de vos, Iohan Munoz e Martin Gutierrez, mis barveros, o de quien vuestro poder oviere, e si el contrario alguno dellos fiziere, que cayga en pena de mill maravedis para la mi cámara por cada vegada. Otrosí, es mi merçed e mando que ningunos ni algunas persona o personas de qualesquier de las dichas çibdades e villas e lugares que non se exsaminen e sean exsaminados ni sean osados de se exsaminar con persona alguna salvo con vos, Iohan Muñoz e Martin Gutierrez, mis barveros, o qualesquier de vos o los que vosotros o qualesquier de vos pusieredes, podades e puedan demandar las cartas de las exsaminaçiones que qualquier de los dichos barveros toviere, porque vosotros por las dichas cartas veades e sepades como son exsaminados e que ayades e levedes de cada un barvero doze maravedis de la presentaçión de cada carta de los que fueren exasminados, e doze maravedis de la confirmaçión de cada una de las dichas cartas. E sobre esto mando e tengo por bien que qualquier o qualesquier de los sobredichos que después de vuestro defendimiento de vosotros o de qualquier de vos o de los dichos vuestros alcaldes que en vuestro lugar pusieredes o de qualquier dellos, usaren del dicho ofiçio, do mi poder conplido a vos, los dichos Iohan Muñoz e Martin Gutierrez, mis barveros. o a qualquier de vos o a los que por vos o qualquier de vos lo ovieren de 
aver e librar para que les podades mandar prendar por las penas que les pusieredes pasando el dicho vuestro mandamiento e defendimiento. Otrosi, mando e tengo por bien que por el afan e trabajo que tomaredes en los dichos exsaminamientos que ayades en salario por el trabajo dos doblas de oro de la Banda o moneda que los vala.

$E$ mando e tengo por bien que ningund barvero non afeyte en domingo ni por las fiestas generales por la Pascua Florida e por la Cinquesma e por la de Sant Iohan Bautista e por Navidad e por la fiesta de los Apostoles ni por las fiestas de Santa Maria en público ni en escondido, so pena de sesenta maravedis a cada uno por cada vegada para los dichos Iohan Muñoz e Martin Gutierrez, mis barveros, e para los que por vosotros pusieredes por alcaldes vuestros, sabiendolo por juramentos de los tales barveros o de los sus ofiçiales o por otras personas en quien quisieredes fazer pesquisa sobre ello, e mando a vos, los dichos Iohan Muñoz e Martin Gutierrez, mis barveros, o a qualquier de vos o al que vuestro poder para lo que dicho es oviere, que los fagades e fagan prendar por la dicha pena. E tengo por bien que ningund aprendiz non sea osado de poner tienda por sí fasta que sea exsaminado por vos, los dichos Iohan Muñoz e Martin Gutierrez, mis barveros, e por los que en vuestros logares pusieredes, e mas, que aya la tienda perdida.

$E$ tengo por bien e es mi merçed que si alguna carta o cartas firmadas de mi nonbre paresçieren en que yo aya fecho merçed del dicho ofiçio de alcaldia a otras qualesquier persona o personas en qualquier manera, que non valan ni fagan fe de aqui adelante, ca yo las revoco e do por ningunas, non enbargante que en esta $\mathrm{mi}$ carta non vayan encorporadas, que yo, de mi propia sabiduria e de mi poderio, las revoco como dicho es. E sobresto mando a los corregidores e alguaziles de las dichas mis çibdades e villas e lugares e a todos los otros ofiçiales qualesquier que agora son como a los que seran de aqui adelante, e a qualquier o qualesquier dellos a quien esta mi carta fuere mostrada o el treslado della signado como dicho es, que se non entremetan a vos defender ningund barvero de los sobredichos, mas que vos ayuden, e a qualquier de vos o a quien por vos o por qualquier de vos lo oviere e librare en 
todos e aquellos casos que vos cunpliere e menester ovieredes para fazer e conplir todo lo que dicho es.

E otrosi, por quanto vos, los dichos Iohan Muñoz e Martin Gutierrez, mis alcaldes, me dixestes que vos reçelavades que en algunas de las dichas mis çibdades e villas e lugares que vos trahieran a pleito e a rebuelta demandando traslado e plazo desta dicha mi carta, por tal de vos traher a rebuelta e luenga por manera que se non cunpla mi mandamiento $\mathrm{n}_{\mathrm{i}}$ podades vos ni algunos de vos exsaminar ni corregir los dichos barveros, mi merçed es e mando que los non consientan ni entremetan de cosa alguna de lo que perteneçe en razon del dicho ofiçio, e mando que los barveros sean enplazados ante los ofiçiales de la mi casa, do quier que yo sea, a exsaminarse con los dichos Iohan Muñoz e Martin Gutierrez, mis alcaldes, e con qualquier dellos e con quien vuestro poder oviere, del dia que les fuera fecho el tal enplazamiento e llamamiento por vos los sobredichos, Iohan Muñoz e Martin Gutierrez o por qualquier de vos, a quinze dias primeros siguientes so pena de dos mill maravedis, la meytad para la mi camara e la otra meytad para vos, los dichos Iohan Muñoz e Martin Gutierrez, mis alcaldes, e para quien vuestro poder oviere para lo que dicho es.

E los unos ni los otros non fagades ni fagan ende al por alguna manera so pena de la mi merçed e de diez mill maravedis para la mi camara a cada uno de vos por quien fincare de lo asi fazer e conplir, e demas por cualquier o cualesquier de vos por quien fincare de lo asi fazer e conplir, mando al ome que vos esta mi carta mostrare o el dicho treslado signado como dicho es, que vos enplaze que parescades ante mi personalmente do quier que yo sea del dia que vos enplazare fasta quinze dias primeros siguientes, so la dicha pena a cada uno a dezir por qual razon non conplides mi mandado; e de como esta mi carta vos fuere mostrada e los unos e los otros la cunplieredes, mando so la dicha pena a qualquier escrivano publico que para esto fuere llamado que de ende al que vos la mostrare testimonio signado con su signo porque yo sepa en como se cunple mi mandado.

Dada en la noble çibdad de Segovia, diez dias de abril año del Nas- 
çimiento del nuestro Señor Jhesuchristo de mill e quatroçientos e çinquenta años. Yo el Prinçipe. Yo Alfonso de Ribera, secretario del prinçipe nuestro señor, la fiz escrivir por su mandado.

\section{VI}

1465-IX-14, Murcia. - Testimonio del concejo de Murcia del examen y suficiencia del cirujano David Abserga.

A todos quantos la presente vieren que Dios honrre e guarde de mal. El conçejo, alcaldes e alguazil, regidores, cavalleros, escuderos, ofiçiales e omes buenos de la muy noble çibdad de Murçia, nos vos encomendamos e fazemos saber por el tenor de la presente, que nos con acuerdo e consejo del honorable maestro Jaime de Limiñana, doctor en las artes de Mediçina e Cirujia, avemos dicernido e dicernemos por avtentico e suficiente çerujano en la arte e çiençia de Cirujia a Davi Abserga, jodio, çerujano, fijo de Mose Abserga, jodio, otrosí çirujano, nuestro vezino. La exsaminaçión e sufiçiençia del qual ovimos encomendado e encomendamos al dicho doctor por virtud del qual vos damos fe e testimonio quel dicho Davi Abserga es ydonio e pertenesçiente para usar del dicho ofiçio de çirugia e segund su sufiçiençia e abilidad le damos e otorgamos facultad e poderio para que pueda usar e use de aqui adelante del dicho ofiçio e arte de çerugia asi en esta çibdad como en otras qualesquier çibdades e villas e logares e partes donde fuere, sin pena nin calupnia alguna. E pedimos e requerimos de parte de nuestro señor el rey e de la nuestra afectuosamente rogamos a todos los conçejos, corregidores, asistentes, alcaldes e alguaziles, regidores e otras justiçias e ofiçiales qualesquier, ante quien esta carta fuere e sera presentada que dexen e consientan usar en sus lugares e jurediçiones al dicho Davi Abserga del dicho ofiçio e arte de çirugia, non consintiendo nin dando lugar que le sea contrariado nin fecho enbargo nin molestia en manera alguna. En fe e testimonio de lo qual mandamos dar e dimos esta nues-

\section{4}


tra carta de exsaminaçión e liçençia escripta en pergamino de cuero e sellada con nuestro sello de tablas pendiente en cintas de seda. Dada en la dicha çibdad a catorze dias del mes de septiembre, año del nasçimiento del nuestro Salvador Jhesuchristo de mill e quatroçientos e sesenta e çinco años.

\section{VII}

1466-VIII-9, Murcia.-Testimonio concejil de las operaciones efectuadas por maestro Diego Sánchez, cirujano de Orihuela.

El conçejo, alcaldes e alguazil, regidores, cavalleros, escuderos, ofiçiales e omes buenos de la muy noble çibdad de Murçia fazemos saber a quantos la presente vieren de como maestre Diego Sánchez, çerujano, vezino de la çibdad de Orihuela, puede aver un año poco más o menos tiempo, quel vino en esta çibdad a usar de su ofiçio; el qual tomó cargo de curar un çaratan urçerado que Isabel Pérez, muger de Alfonso Palazol, notario, vezino desta dicha çibdad, tenía en la teta derecha, e seyendo sana de la dicha llaga, por los dichos Alfonso Palazol e su muger como por otras personas, fue puesta dubda quel dicho maestre Diego pudiese aver curado del dicho çaratan a la dicha Isabel Perez segund la dispusiçion de la llaga e del logar en que estava e que por tienpo le devia retornar. $E$ recelando esto fue pedida fiança al dicho maestre para seguridad de la dicha cura, porque de otra guisa non le quería pagar la cantidad que con el se avía igualado. Sobre lo qual amas las partes ovieron de venir a nuestro ayuntamiento quexándose la una de la otra, de guisa que nosotros ovimos de encomendar a Alfonso de Dávalos e Diego Riquelme, regidores en esta çibdad, para que en uno con maestre Jayme de Limiñana, doctor en las artes de Medeçina e Cirujia, e con Juan de León, e maestre Benito, e maestre Yuçaf e otros çurujanos viesen la dicha llaga e diesen con su acuerdo e consejo aquel remedio que en cargo de sus conçiençias entendiesen quera conplidero, por manera 
que la una parte e la otra non resçibiesen agravio. Los quales entendieron en el negoçio e sobre mucha pratyca e fabla sobre por ellos avida, determinaron que al dicho maestre Diego le fuese fecho pago del preçio que con el se avían igualado, e quel diese fiador que sy fasta el sant Juan de junio postrimero pasado le bolviese la dicha dolençia, quel fuese tenido a bolver el dicho dinero, e que desto diese fiança. La cual el' dió e quarenta días más del tiempo que los dichos çurujanos mandaron, e si la dicha llaga en este tienpo non retornase, quel dicho Alfonso Palazol le diese e pagase demás de la cantidad del presçio que con el se avía igualado, mill maravedis más.

E después del dicho término pasado, nosotros a requesyçion del dicho maestre Diego mandamos aver informaçion de como la dicha Isabel Pérez era sana de la dicha llaga del dicho garatan. De lo qual el dicho maestre Diego nos pidió le mandasemos dar e diesemos nuestra carta de fe e testimonio sobrello. E nos, vista su petiçión ser justa, mandamosle dar la presente, por la qual vos fazemos fe e testimonio lo susodicho seer e aver pasado en la manera susodicha, e el dicho maestre Diego aver sanado del dicho çaratan a la dicha Ysabel Pérez. En fe e testimonio de lo qual le mandamos dar e dimos la presente, firmada de los nombres de algunos de nos los dichos regidores e ofiçiales e sellada con nuestro sello. Fecha a nueve dias del mes de agosto, año del nasçimiento del nuestro Salvador Jhesuchristo de MCCCCLXVI años.

Testimonio que tomó maestre Diego çurujano de las curas que fizo de los çaratanes.

El conçejo, alcaldes, alguazil, regidores, cavalleros, escuderos, ofiçiales, a omes buenos de la muy noble çibdad de Murçia, fazemos saber a todos quantos la presente vieren de como maestre Diego, çurujano, vezino de la çibdad de Orihuela, por nuestros ruegos tomó cargo en nuestro ayuntamiento de curar a Teresa, muger de Juan Yáñez, vezino de Aledo, un çaratan urçerado que ante nosotros mostró que tenía en la teta derecha, el qual el non quería curar. $\mathrm{E}$ con toda diligençia curó de la dicha llaga e le sanó della, segund que a ojo nosotros lo vimos en nuestro ayuntamiento. De lo qual el dicho maestre Diego nos pidió que le 
diesemos nuestra carta de fe e testimonio dello, e nosotros, vista su petición ser justa, mandamosle dar e dimos la presente. Por la qual vos fazemos fe e testimonio quel dicho maestre Diego sanó a la dicha Teresa del dicho çaratan e es e fynca sana dello segund e como dicho es de suso. En testimonio de lo qual le mandamos dar e dimos la presente firmada de los nombres de algunos de nos los dichos regidores e ofiçiales, e sellada con nuestro sello. Fecha a nueve dias de agosto, año de mill e quatroçientos e sesenta e seys años. 